\title{
Alice and Bix
}

\section{Albert Haim and Chris Barry}
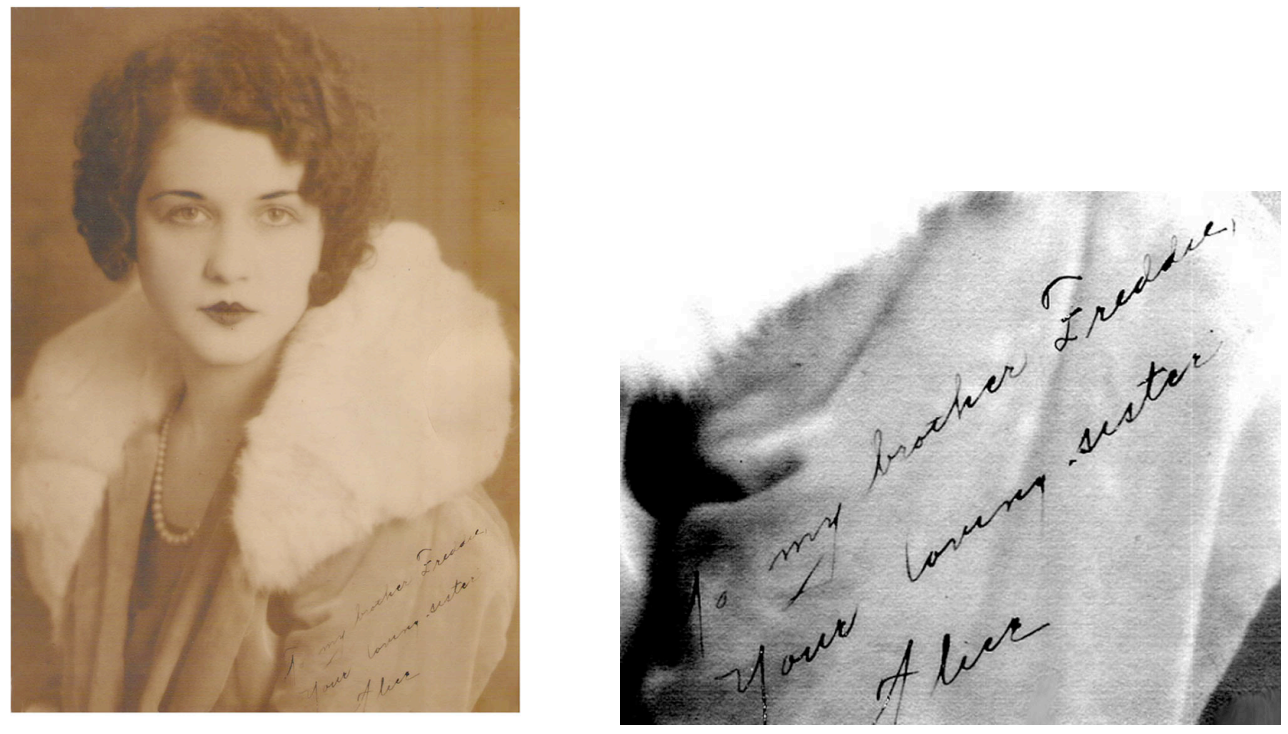

Figures $1 \& 2$. Alice Regina Weiss, courtesy of her niece Alice Clare Weiss with closeup of dedication.

\section{PRELUDE}

She still gazes at us, from more than eighty years ago, through a sepia tone photograph. Her bright eyes are fixed right on you. Her close-cropped, wavy hair and soft features are framed by a generous fur collar and beaded necklace. But there will be no first hand recollections from one of the last people to know Bix Beiderbecke. We are thirty years too late. She died in 1982. She had no children. She told her siblings about her relationship with Bix, but they're all gone, too. Many of her personal papers were discarded when her last sibling, her youngest sister, died in 1995. But we know who the lady in the photograph is, and with the generous help of several members of the Weiss family, we have uncovered quite a bit of information about her. Alice Regina Weiss was born in 1906 in New York, the ninth child of Theodore Carl Weiss 
and Helen "Nellie" O'Connell, and died in West Islip, New York, in 1982. Alice was married twice, first to Rex Gavitte (1926-1932), and then to Max Weiss (1942-1967). Alice was the closest person to Bix in the last weeks of his brief life.

\section{INTRODUCTION}

After spending several months at home in Davenport recuperating from poor health and excessive drinking, Bix Beiderbecke returned to New York early in 1931 to resume working. He moved into his usual residence while in the city, room 605 in the $44^{\text {th }}$ Street Hotel at 120 West $44^{\text {th }}$ Street between Broadway and $6^{\text {th }}$ Avenue. Bix first resided at the $44^{\text {th }}$ Street Hotel in October of 1926 when the Jean Goldkette Orchestra had an eleven-day engagement at Roseland that included a "Battle of the Bands" with Fletcher Henderson's orchestra.

In 1931, Bix did not have a steady job. From March to June, he picked up a few gigs in colleges in the Northeast: Amherst College with the Dorsey Brothers (March 14); Princeton University with Benny Goodman, Jimmy Dorsey and Tommy Dorsey (May 1 and 2); Yale University with the Dorsey Brothers (May 15); and Williams College with Benny Goodman (June 10 and 11).

With Bix's return to work came the resumption of his unhealthy drinking habits. Bix visited Smith Ballew and His Orchestra at Saltzman's Restaurant in the Lincoln Building (60 East $42^{\text {nd }}$ Street) on June $12 .{ }^{1}$ Trumpeter Jimmy McPartland remembered seeing Bix around this time and recalled, "He had been drinking excessively and not eating much." ${ }^{2}$ Bix tried to sit in with Ballew's band at Saltzman's, but guitarist George Van Eps recalled Bix was only physically able to play piano, not cornet. The band's bassist, Rex Gavitte, decided that Bix needed help and took him to his home on Long Island where Rex and his wife could care for Bix. ${ }^{3}$

According to the 1931 AFM Local 802 directory, Gavitte's address was $246032^{\text {nd }}$ Street, Astoria, New York. This is also the temporary address that Bix gave to his parents in a letter written June 16, 1931. In the letter, Bix told his parents that he planned on marrying a woman named Alice O'Connell. For decades, Bix historians and fans have searched for Alice O'Connell, but the

\footnotetext{
${ }^{1}$ Philip R. Evans and Linda K. Evans, Bix, The Leon Beiderbecke Story, (California: Prelike Press, 1998), 540.

${ }^{2}$ Jean Pierre Lion, Bix: The Definitive Biography of A Jazz Legend (New York, Continuum, 2005), 273.

${ }^{3}$ Evans and Evans, 540.
} 
woman's identity remained elusive. In the present article, we present the results of the investigations that led us to a positive identification of Bix's Alice.

\section{ALICE O'CONNELL AND HELEN WEISS}

The first mention of a young woman named Alice O'Connell, Bix's "future wife," is found in the letter of June 16, 1931 written by Bix to his parents. The complete letter, transcribed below, was first published in its entirety in $1998 .{ }^{4}$ However, already in 1976 Bixophile/collector Joe Giordano visited Mary Beiderbecke (Bix's sister-in-law) in Davenport and saw this letter and several others that Bix had written to his parents. In 1979, Curtis Prendergast, in the booklet that accompanied the Time Life Giants of Jazz set on Beiderbecke (Time Life Records, STL-J04, 1979), cited the name Alice O'Connell, described her, and transcribed a few sections of the letter. In 1990, Chip Deffaa quoted extensively from Bix's letter in Voices of the Jazz Age. ${ }^{5}$

A complete transcript of Bix's letter, with the spelling and punctuation exactly as he wrote it, follows here (see Appendix, Figures 3A-E for scans of the original letter).

"Dearest Mom \& Dad:

This time I have a pretty legitimate excuse for not having written. I had a sudden offer to take my own musicians on the road-the fellows I used on records. I was in pretty much of a sweat-Burnie will tell you what onenighters are. I stood up part of the time in swallow tails and directed. 3 weeks around New England and P.A. coal region-of course I played too.

I hope you are all well- \&now about my future wife-Born in N. Y. never been .out-you should hear her accent-sounds like Aunt Blanch (2) Red Headed- Blue eyes (3) Mother's name was Weiss-Dad's name O'connellGerman-Irish, not bad-huh?

Here is something I've been dreading to say because of mother-she's a staunch catholic she has dragged me to her mass 3 or 4 times trying to convert me, and I've taken her to the $5^{\text {th }}$ Ave pres. Church-she says she likes it but her two brothers \& 3 sisters would squeak-I played golf with one of her brothers and he was very broad-minded about it-now if I can swing the sisters-They're all nice and encourage our marriage-they all like me.

I told Alice that I wouldn't get married until I had a couple thousand-she winked at me and said "you've got it" and showed me a bank book-I almost swooned-she's got bonds bank stocks etc and plenty in the bank-I promise you that I fell in love with her before I knew that.

\footnotetext{
${ }^{4}$ Evans and Evans, Bix, 540-541.

${ }^{5}$ Chip Deffaa, Voices of the Jazz Age by, (Champaign, IL, University of Illinois, 1992), 98-99.
} 
I'm sending a picture of her-what do you think of her? She had no pictures so I dragged her in to Photomators [sic] on B'way when we were in the city and for a buck we got this huge picture-Alice didn't want to send it to you until she got a good one made. This will give you an idea of her.

Her mother and father died when she was quite young-They apparently were very wealthy-Alice is 20 years old-when they died she spent 9 years in a convent-The two other brothers and three sisters all had a split in the estateI think Alice is worth $\$ 10,000$ at least with her bonds etc \& I didn't know it. TEAR THIS UP

I have two offers pending and I'm thinking both over-they're both at lakes outside of N. Y.-so I can come in for records etc. the highest bidder wins-I'll give you my definite address in a few days-until then-2460 $32^{\text {nd }}$ st Astoria, L. I.

My best love

Bix

P.S. Have mom tell me what to do about cathotic [sic].

In his last letter to his parents, July 30, 1931, unfinished, Bix writes, "By now you have Alice's picture ... The little sweetheart framed it, packed it, and sent it to you when she knew you wanted it."

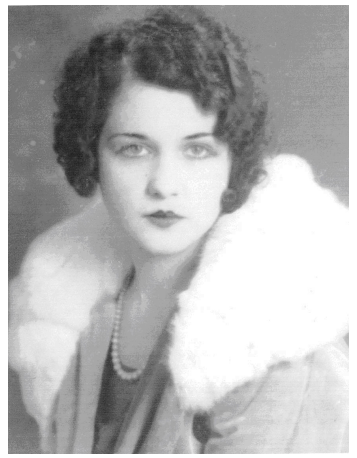

Figure 4. Photo sent to Bix's parents in June 1931, from Evans and Evans, p. 543.

It will be seen that this photograph is the same as the one that Alice gave to her brother Freddie.

Bix provides quite a bit of information about Alice. She is 20-years old, a New Yorker; her father was Irish, O'Connell, and her mother was German, Weiss; she has several brothers and sisters. The names "Alice O'Connell, N. Y." and "Weiss Family, N. Y." are listed in the "Register of Friends Who Called at the Services of Leon Bix Beiderbecke" under "Friends Who Sent Flowers."6

\footnotetext{
${ }^{6}$ Evans and Evans, Bix, 550-551.
} 


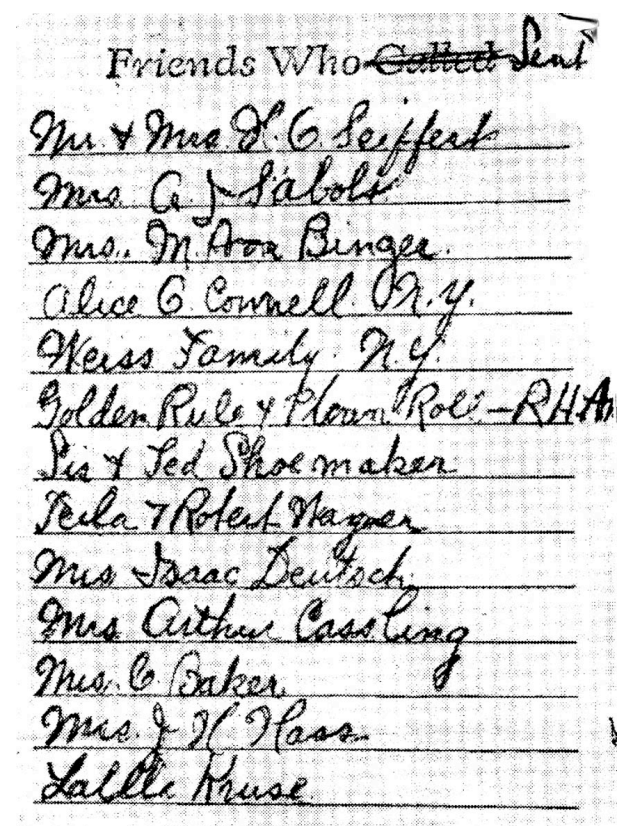

Figure 5. Bix Beiderbecke's Register: Friends who sent flowers. From Evans and Evans, p. 551.

The name Helen Weiss first appeared in Richard Sudhalter and Philip Evans's 1974 biography, Bix, Man and Legend. ${ }^{7}$ At the time the book was written, the authors were unaware of Bix's letter to his parents with the mention of Alice and of the "Register of Friends who Called at Bix's Services" with the listing of Alice O'Connell as having sent flowers. Sudhalter and Evans reported that Bix moved to Rex Gavitte's apartment in Astoria in June 1931, and, shortly after, to a brand new building at $433046^{\text {th }}$ Street in Sunnyside, about two miles from Gavitte's residence. According to Evans and Evans, "Bix's new surroundings contained only a bed, a bureau, and a piano." Sudhalter and Evans also reported that in mid-July, Hoagy Carmichael invited Bix and his girlfriend to his apartment at 114 East $57^{\text {th }}$ Street in Manhattan. Hoagy's recollection was that the girl's name was Helen Weiss and that Bix looked great. ${ }^{9}$

Sudhalter and Evans further reported that, in the summer of 1931 Bix wrote to his childhood friend, Esten Spurrier. In his letter, Bix mentioned that

\footnotetext{
${ }^{7}$ Richard M. Sudhalter and Philip R. Evans, Bix, Man and Legend (New York, Arlington House, 1974), 327.

${ }^{8}$ Evans and Evans, Bix, 543.

${ }^{9}$ Sudhalter and Evans, 327.
} 
he had purchased a piano and that "at last, he had fallen in love."10 George Kraslow, the rental agent for the new building in Sunnyside, confirmed that there was a piano in Bix's apartment and that an extremely attractive girl had helped Bix pick the apartment and visited him a few times afterward.

Sudhalter and Evans concluded this section of their book as follows: "Some things may never be clarified, such as the extent of his (Bix's) relationship with Helen Weiss. Rumor persists that they became engaged sometime in July. But all attempts to find Miss Weiss have proved fruitless. There seems little possibility now of establishing the facts."

Helen Weiss is also mentioned in Evans and Evans' biography. ${ }^{11}$ Hoagy Carmichael told Philip Evans that Helen Weiss who "lived in Sunnyside near Jackson Heights" helped Bix move to Long Island. Bix moved to his new apartment in late June-early July 1931. Evans and Evans report that "Bix and Helen Weiss, his new girlfriend, visited Hoagy Carmichael's apartment at 114 East $57^{\text {th }}$ Street."12 Carmichael told Evans, "Bix was in good shape. I told the girl to please call me immediately if anything happens." In one of his autobiographies, Sometimes I Wonder, Hoagy wrote: "She [no name given] was Bix's kind of girl. A bit mothery [sic], maybe lost herself, but neat, willing to put up with Bix's habits. I liked her. We didn't have a drink. We didn't talk much music, and it became apparent that this girl had no idea who Bix was and why he was the way he was. It was just two strangers meeting. Perhaps she knew he was a musician, but that was all. The thought struck me-later-I didn't know Bix either. He was my friend, yet intimately, deeply, warmly, I didn't know him. He was unfathomable, the bit on the surface hiding the deeplying man."13 As we will see presently, there is more rhetoric than fact in Carmichael's account.

Carmichael's description of Bix's girlfriend is inconsistent with her photograph and with the account of Stephen Ickes who wrote to Evans on December 19, 1972: “About Helen Weiss, I don't know her whereabouts, but I gathered she knew Bix in 1930 when he played on the Camel Hour and knew someone who was living in the building where Bix moved. She was able to find him an apartment and visited him. She was connected with the entertainment field. I understand she was dark haired, blue eyes, and very beautiful. Other notables that lived there were Rudy Vallee and the man who

\footnotetext{
${ }^{10}$ Sudhalter and Evans, 327.

${ }^{11}$ Evans and Evans, Bix, 542.

${ }^{12}$ Evans and Evans, Bix, 545.

${ }^{13}$ Hoagy Carmichael with Stephen Longstreet, Sometimes I Wonder, (New York, Farrar, Straus and Giroux, 1965), 225.
} 
did the voice of Popeye."14 Moreover, Carmichael's assertion that Bix's girlfriend "had no idea who Bix was" is incompatible with the fact that Rex Gavitte was a musician himself. Gavitte, who certainly knew of Bix's reputation as a first-class cornetist and pianist, had brought him to his apartment. And it is believed that is when Alice began to take care of him.

On August 6, 1931, Bix died in his apartment in Sunnyside, alone. The official cause of death was lobar pneumonia. Carmichael reports that Bix's girlfriend whom he identified as Helen Weiss or Miss Weiss (in reality, Alice Weiss) gave him Bix's handkerchief, his cuff links and his Holton mouthpiece. Hoagy kept the mouthpiece. He donated the handkerchief and cuff links to the Louisiana State Museum in 1963. Following is a transcript of the letter from Hoagy Carmichael to the officials of the Museum:

November 9, 1963

Mr. H. Clay Watson

New Orleans Jazz Museum

1017 Dumaine Street

New Orleans, Louisiana

Dear Mr. Watson:

I have been considering your request of August 6 and I have decided to send you a couple of articles that belonged to Bix Beiderbecke.

Enclosed you will find the handkerchief and pair of cufflinks [sic] that he was wearing just before his last illness. The occasion may well have been the engagement at Princeton University that he attempted to make when he contracted pneumonia. This was verified to me by Miss Weiss, who lived in the same apartment building in Sunnyside, Long Island, at the time of his illness. They had been dating for some weeks. In fact they visited me in my apartment just a week before his illness. She sent these articles to me a few days after his death.

Knowing Bix, he may have had another handkerchief or two but it is quite possible that this is the only pair of cufflinks [sic] he had at the time. However, I cannot vouch for this.

I hope these little articles will be of some help in the establishment of the New Orleans Jazz Museum but I want to make clear that they are strictly museum articles and may not be sold or exchanged by any individual or corporation for personal or corporate benefits. I am sure you agree this is the proper procedure and I am, therefore, enclosing a copy of this letter for you to sign where indicated and return it to me.

I am sure you are doing a fine job in your capacity and I hope the Museum flourishes as it should.

\footnotetext{
${ }^{14}$ Evans and Evans, Bix, 544.
} 
Sincerely yours

Hoagy Carmichael

$\mathrm{HC} / \mathrm{bm}$

enc. (3)

Accepted:

Date: Signature

P. S. You may launder the handkerchief, if you wish, but perhaps it is better to display it in its present state of age.
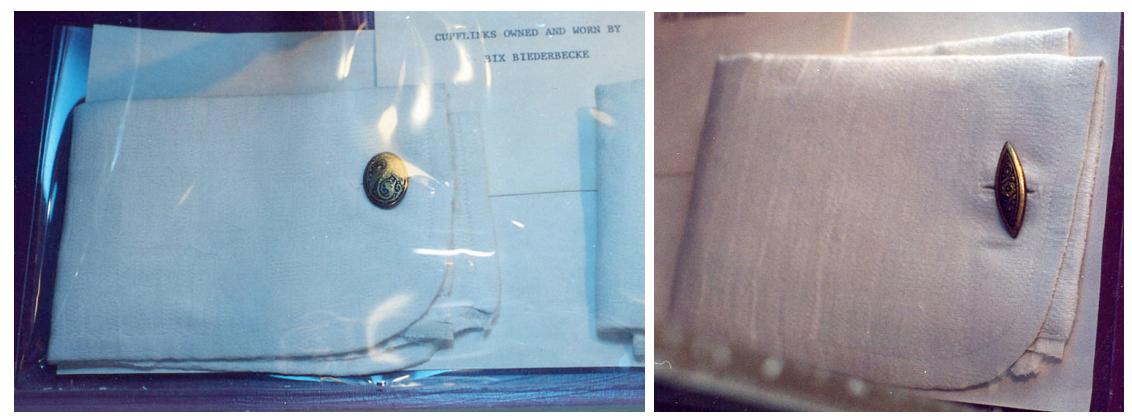

Figures 6A-B. Bix's Cuff Links in the Louisiana State Museum. Photos Courtesy of Enrico Borsetti

When notified by Frank Trumbauer that Bix was seriously ill, late on August 5, Bix's mother Agatha and brother Charles "Burnie" rushed from Davenport to Sunnyside, but arrived too late. In a letter dated February 21, 1967, Burnie told Phil Evans, "I am quite certain, too, that Miss Weiss had made all the arrangements to have Bix's body shown. It was my mother's impression as well as mine that Bix was engaged to Miss Weiss."15 The Beiderbecke family took back to Davenport some of Bix's personal effects and his \#620 Vincent Bach Stradivarius cornet. When Agatha Beiderbecke, Bix's mother, died in 1952, the cornet was inherited by Mary Louise Shoemaker, Bix's sister. When she died, her son Charles Bix Shoemaker took possession. He sold it to Robert Christiansen in 1990 who in turn donated it to the Putnam Museum in July 1997. The fate of Bix's piano will be discussed below.

\section{ALICE O'CONNELL, ALICE WEISS, OR ALICE GAVITTE?}

Several Bix researchers made vigorous attempts to find Alice O'Connell, but none of the women with that name in the New York City area around 1930 seemed to match Bix's description. In 1976, Bixophile Joe Giordano, in a visit to Davenport, had a chance to see Bix's letters to his parents and wrote about 500 letters to people with the last name O'Connell in the New York area, but was unable to discover the identity of Alice O'Connell. Some researchers

${ }^{15}$ Evans and Evans, Bix, 549. 
speculated that there were two different women, one Alice O'Connell, the other Helen Weiss, perhaps Alice's cousin on her mother's side (this assumes that the maiden name of Alice's mother was Weiss, as stated by Bix in his letter to his parents). Research into a Helen Weiss also failed to find a match.

Chis Barry decided to focus his research on Rex Gavitte. This avenue of investigation led to the identification of the woman in the photo Bix said Alice sent to Bix's parents as Alice Gavitte, née Weiss.

Rex Brinton Gavitte was born on August 4, 1899, in Pennsylvania, the son of Edward B. Gavitte, MD, and Sarah Richards. Rex attended West Virginia University (his photo appears in the year book, The Monticola, of 1920). Rex apparently was married by January of 1920. The 1920 U.S. Census lists Rex "Gabbot" as son-in-law in the household of Charles and Anna Buseman, along with their daughter, Pearl "Gabbot," all residing at 700 Beechurst Avenue, Morgantown, West Virginia. No marriage record for Rex and Pearl has been located. The 1922 Morgantown city directory lists Rex Gavitte, student, and Pearl living at 387 Beechurst Avenue, Morgantown.

At some point Rex and Pearl parted ways, but it is not known when or where. Rex was a working musician in New York City by February of 1924. At the February 20, 1924 Executive Board meeting of Local 802, the Trial Board recommended that Rex Gavitte's transfer from Local 562, the Morgantown chapter, be revoked for an infraction of Art. X Sec. 12 of the National Law of the union. Causes for revocation were, among others, non-payment of dues or assessments.

According to the AFM Local 802 directory, Rex Gavitte's address in 1931 was $246032^{\text {nd }}$ Street, Astoria, Long Island. As mentioned above, the address is identical to that given by Bix to his parents in his June 16 letter. At this point, a very significant discovery was made: the same address, $246032^{\text {nd }}$ Street, was listed for an Alice Gavitte in the 1930 U.S. Census for the borough of Queens, New York City, New York, enumerated on April 4, 1930. Alice Gavitte is listed as age 20, white, born in New York, married when she was 17, her father was born in Germany and her mother was born in Ireland. Alice Gavitte is the head of the household; her sister Vera Weiss, age 17, white, born in New York, single, is the only other member of the household. The nationalities of Vera's parents are the same as Alice's. We note that Alice gives false ages for herself at the time of the 1930 U.S. Census-she was 23-as well as for her sister Vera, née Veronica, who was 19 in 1930.

Rex Gavitte and Alice Weiss were married in Philadelphia on April 10, 1926. At the time, Rex's mother lived in Philadelphia. Divorced from her husband Edward, father of Rex, she was now Sara G. Higgins, and was a 
witness at the wedding. Rex and Alice visited Rex's father in New Enterprise, Bedford County, Pennsylvania, in early August 1929.

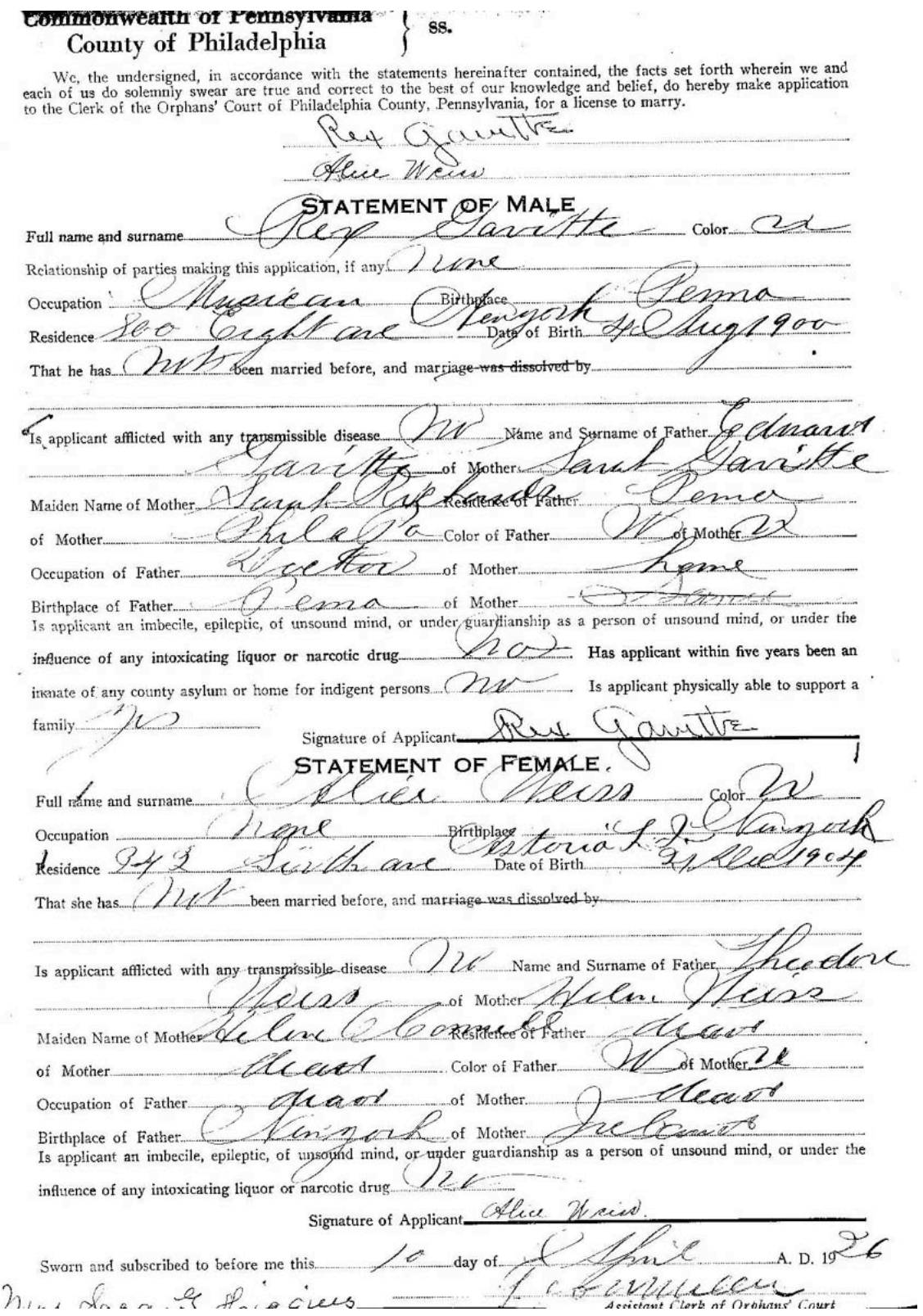

Figure 7. Application for License to Marry 
Both Rex and Alice gave false information about their birth years in their marriage certificate: Rex gives 1900 when it was, in fact, 1899; Alice gives 1904 when it really was 1906, as demonstrated in her birth certificate:

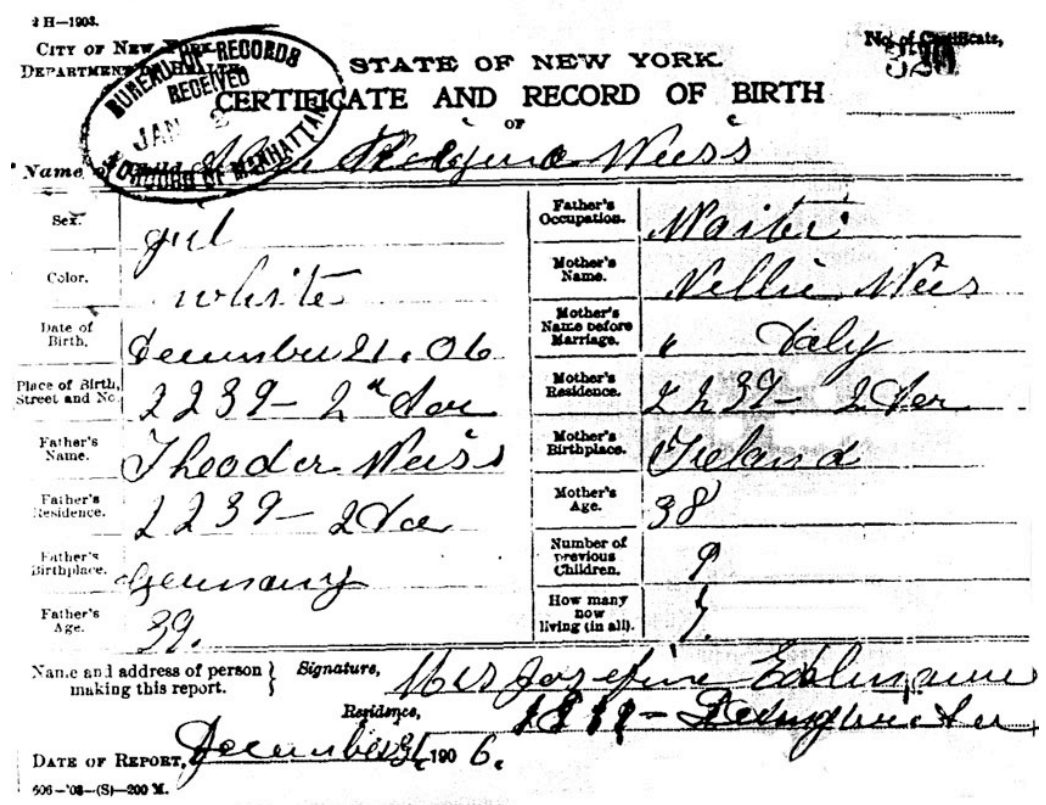

Figure 8. Certificate of Birth, Alice Weiss

Nellie's maiden name is given as what seems to be Daly. This is clearly an error. In the birth certificate of Alice's brother Philip we can see that Nellie's maiden name is O'Connell (See Appendix, Figure 9. Birth Certificate of Philip Weiss).

Gavitte also lied about not having had a previous marriage when he married Alice Weiss. On her application for a license to marry, Alice gives her father's name as Theodore Weiss, born in New York, and her mother's name as Helen O'Connell, born in Ireland. Alice's birth certificate gives Theoder [sic] Weiss, born in Germany, as her father and Nellie Weis [sic], born in Ireland, as her mother.

It was becoming evident at this point that Alice's maiden name was Weiss, not O'Connell, and that she most likely was the woman that Bix was seeing in June and July 1931 and had described to his parents. Therefore, the Weiss connection was investigated.

THE WEISS FAMILY

Theodore Carl Weiss, sometimes referred to as Carl Theodore Weiss, was born on October 18, 1869, in Germany. He arrived at the Port of New York 
on January 5, 1885, aboard the S.S. Salier, along with his mother and two siblings. At some point, Theodore met Helen "Nellie" O'Connell, an Irish immigrant born in 1871, daughter of Philip O'Connell and Frances Benson. Theodore and Helen married on June 4, 1890, at Our Lady Queen of Angels Roman Catholic Church, 228 East 113th Street, in Manhattan. Theodore and Nellie would have 11 children, born between 1892 and 1911. Two died young, before 1899. One was Helen Weiss, who died at age 1 in 1895 in what was termed an accidental drowning "by falling in a tub of water placed upon the floor." The nine surviving children were:

Florence Kathleen, 1892-1918; married John McCarthy, one child, Florence.

Lillian Pauline, 1896-1916; never married.

Mary Wilhelmine, 1898-1971; never married.

Frances Nora, 1901-1972; never married.

Raymond Theodore, 1903-1973; married Margaret, two children, Raymond A. and Ronald G.

Philip Patrick Joseph, 1905-1951; married Jeannette, two children, Joan (married Nicholas F. Fabrizio) and Philip John.

Alice Regina, 1906-1982, married twice; first, Rex Gavitte in 1926 and then Max Weiss in 1942; no children.

Frederick Joseph, 1908-1984, married Edna, two daughters, Alice Clare (married Willie Kimble) and Ellen.

Veronica Weiss, 1911-1995, married Philip M. Monaghan; no children.

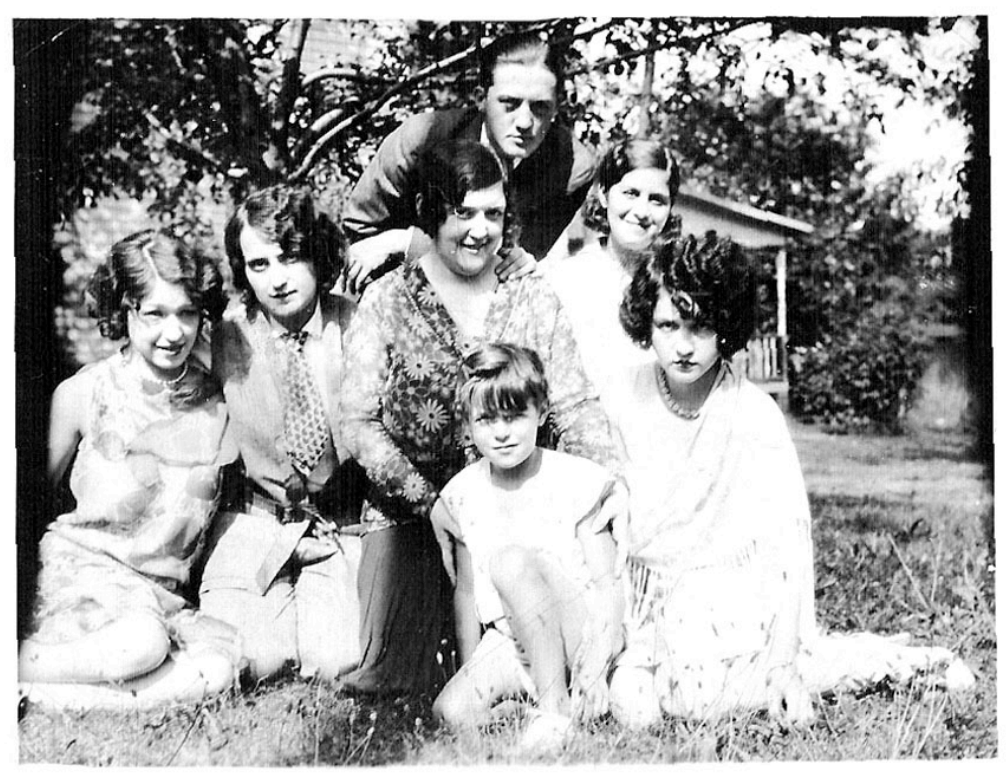

Figure 10. Several Members of the Weiss Family. Courtesy of Alice Weiss Kimble. From left to right, Veronica, Margaret, Mary, Raymond Theodore, Jeanette, Alice. Young girl in front is Florence McCarthy. 
The couple's ninth child, Alice Regina Weiss, is the person of interest here. Three of Alice's siblings were of crucial importance in our investigation. Philip Patrick Joseph Weiss, ${ }^{16}$ father of Joan Fabrizio, who identified the woman in the photograph reproduced in the biography by Evans and Evans; Frederick Joseph Weiss, ${ }^{17}$ father of Alice Clare Kimble, who kindly sent a scan of the photograph Alice Regina had given to her brother Frederick Joseph; and Raymond T. Weiss, ${ }^{18}$ grandfather of Raymond Anthony, Jr., Patricia, and Douglas Weiss who shared with us their collections of photographs and documents. In addition, conversations with Joan Fabrizio, Alice Kimble, and Raymond Anthony, Jr., Patricia and Loretta Weiss were extremely helpful in our investigations.

The 1910 U.S. Census for Manhattan, 2239 Second Avenue, lists the following members in Theodore Weiss' household: Theodore 41, Nellie 39, Florence 17, Lillian 14, Minnie (Mary) 11, Fanny (Frances) 9, Theodore

\footnotetext{
${ }^{16}$ Phillip [Philip] Patrick Joseph Weiss was born on March 18, 1905, at $22392^{\text {nd }}$ Avenue, Manhattan, and died about 1951. Philip and Jeanette Weiss had two children, Philip and Joan Phyllis Weiss, who married Nicholas F. Fabrizio. From the Orlando Sentinel, October 13, 2000: “JEANNETTE WEISS, 90, Pleasant Grove Drive, Winter Springs, died Monday, Dec. 11, of congestive heart failure. Mrs. Weiss was an office worker. Born in New York, she moved to Central Florida in 1975. She was a member of Sts. Peter and Paul Catholic Church. Survivors: daughter, Joan Fabrizio, Winter Springs; son, Philip, Congers, N.Y.; six grandchildren; seven great-grandchildren. Baldwin-Fairchild Funeral Home-Goldenrod Chapel, Winter Park."

${ }^{17}$ Frederick Joseph Weiss was born on October 28, 1908, at 2239 2nd Avenue, Manhattan; and died on May 17, 1984, in Tallahassee, Leon County. From the Tallahassee Democrat, May 18, 1984: "Frederick J. 'Fred' Weiss, 75, 2038 Longview Drive, died Thursday in Tallahassee Memorial Regional Medical Center. Friends may visit today from 7 to 8 p.m. at Bevis Colonial-Fletcher R. Dunaway Funeral Home. Funeral services and burial will be held in Miami. He was a native of New York City and moved to Tallahassee from Miami in 1981. He was a restaurateur before retiring and was formerly a chauffeur for Ethel Barrymore. He was a Catholic. Survivors include his wife, Edna Weiss of Tallahassee; two daughters, Alice Kimbel [sic] of Tallahassee and Ellen Weiss of Miami; a sister, Veronica Monaghan of Hasbrouck Heights, N.J.; a sister-in-law and two grandchildren."

${ }^{18}$ Raymond Theodore Weiss was born on May 18, 1903 at 2239 2nd Avenue, Manhattan, New York City; and died on November 23, 1973 in or near Commack, Suffolk County, New York. From the New York Times, 24 Nov. 1973:"WEISS - Raymond Theodore, on Nov. 23, 1973, retired N.Y.C. Police Lieutenant and retired school teacher from Henry School, Jamaica, N.Y. and Brentwood West Jr. H.S., beloved husband of Margaret, dear father of Raymond A., Ronald G. White, fond brother of Fred and Alice Weiss and Vera Monaghan, also survived by six grandchildren and one great-grandchild. Reposing at the Casimir Funeral Home, Route 112, Pt. Jefferson Station, N.Y. Visiting 2-5 and 7-10 P.M. Funeral Monday 9:15 A.M., Mass of the Resurrection, Christ the King R.C. Church, Commack, N.Y. 10 A.M. Interment St. Raymond's Cemetery."
} 
(Raymond) 6, Philip 5, Alice 3, Fredrick 1, Philip O'Connell (father in law) 65.

September 1916 was doubly tragic for the Weiss family. Alice's 20-yearold sister Lillian, a telephone switchboard operator, died September 15 at home, 448 East 79th Street, in Yorktown, Manhattan's Germantown. On September 22, one week later, almost to the hour, their father, Theodore, also passed away at home. Both Lillian and Theodore died from pulmonary tuberculosis. Alice's sister Florence, wife of John McCarthy, died on October 22, 1918 from lobar pneumonia, leaving an 8-month-old daughter.

In 1920, Alice's mother Nellie was living at 2094 3rd Avenue in East Harlem. The U.S. Census for 1920 lists the following as members of the household: Nellie 44, Mary 20, Frances 18, Raymond 16, Philip 14, Alice 12, Frederick 10, Vera 8. Nellie would die at this residence March 16, 1925, from "Coronary sclerosis."

The 1925 New York State census lists the following members of the Weiss family living at 2094 Third Avenue, Manhattan: Mary, head, age 25, telephone operator; Raymond, brother, age 21, salesman; Francis, sister, age 24, operator, Western Union; Philip, brother, age 19, laborer; Alice, sister, age 17, housework; Freddie, brother, age 15, school; Vera, sister, age 12, school.

\section{BIX'S ACCOUNT AND THE FACTS}

Let's go over some of the personal details about Alice that Bix outlined in the letter to his parents dated June 16, 1931. Bix's account of Alice and her family is, in part, consistent with the known facts, but it also includes some minor as well as major discrepancies. We list here some of these:

- Bix writes that Alice was born in New York City and had "never been out." However, we know from the record of her marriage to Rex Gavitte that she had been out of town at least once. We do not know if Bix was aware of Alice having gone to Philadelphia.

- Bix gives Alice's age as 20. We know, from her birth certificate, that she was 24 when she met Bix. There is no special significance to this discrepancy; Alice fibbed about her age before and after knowing Bix.

- Bix writes that Alice has two brothers and three sisters. In fact, Alice had three brothers and three sisters still living in 1931. Raymond Weiss, age 26, lived in the borough of Queens with his wife Margaret, age 25. Raymond was a policeman. Philip Weiss, age 23, lived in the Bronx with his wife Jean, age 18. Philip was a plumber at this time. Frederick Weiss, age 21, single, lived in the 
Metropolitan Hospital, Welfare Island (now, Roosevelt Island), occupation, kitchen helper. The three sisters, still alive, and all unmarried, were Mary, Frances and Vera. In 1930, as indicated above, Vera was living with Alice in Queens. Mary and Frances, both single, were living together in Manhattan.

- Bix stated (twice) that the photo of Alice sent to his parents was taken in a "photomators" store for one dollar. That is highly unlikely, if not impossible: the photo is of high quality and appears to have been taken by a professional photographer. Additional evidence for the photo being a studio photograph comes from the existence of a similar photo, most likely taken on the same day (see Figures $1 \& 11$ ).

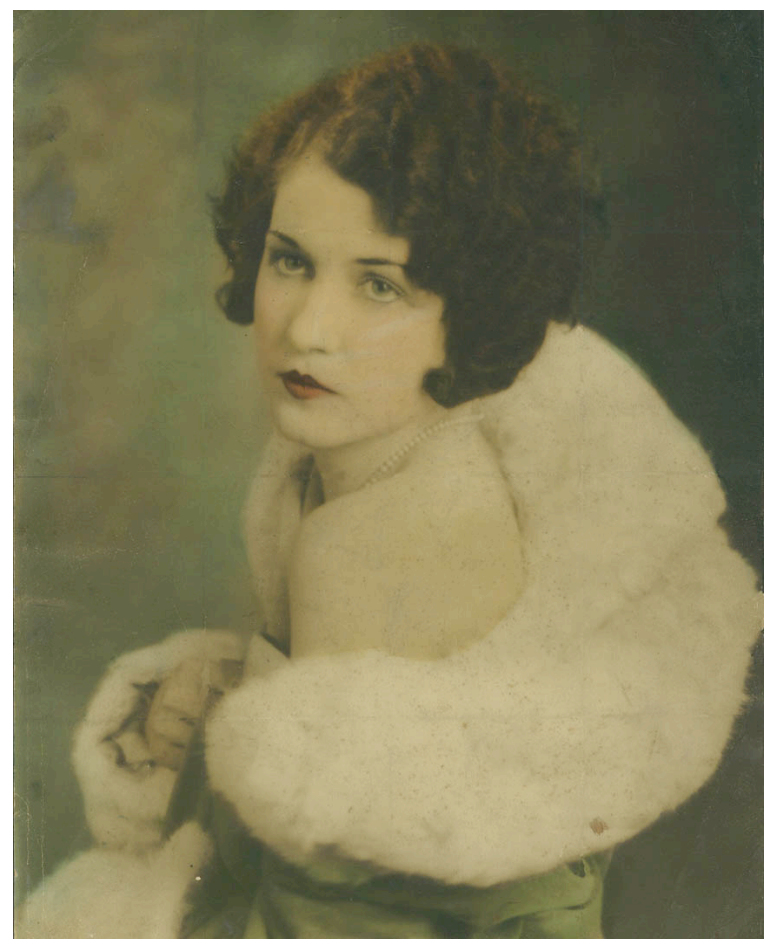

Figure 11. Alice Weiss. Courtesy of Raymond A. Weiss, Jr.

It will be seen that Alice is wearing the same coat and necklace. It seems curious to us that, although Bix conveys to his parents that his work made him financially secure, and that Alice came into a fortune, Bix also makes what sounds like a penny-wise point to mention that the photo he mailed cost only "a buck." 
- Bix writes, "Her mother and father died when she was quite young," and "when they died she spent nine years in a convent." Alice's father died when she was nine, indeed "quite young." However, Alice was still living with her mother in 1920. Nellie died in 1925 when Alice was 18. Alice married Rex Gavitte the following year, so she was not "quite young" when her mother died and it does not seem possible that she "spent 9 years in a convent." We don't know whether Bix or Alice provided the incorrect information.

- Bix writes of Alice's parents, "They apparently were very wealthy." While there are no eyewitnesses to verify that Alice flashed a huge bankroll, it is known that Alice's family had no fortune. Her father was a waiter and steward. Was Bix willfully misleading, or was he merely reporting what he was told? Or perhaps Alice had her own source of money?

- The major discrepancy relates to Alice's last name, both maiden and married names. Alice O'Connell? Bix writes her father was Irish, name O'Connell, and her mother was German, maiden name Weiss. In June 1931, Bix was living with Rex Gavitte and his wife, Alice Gavitte, née Weiss. The documentary evidence for Alice Weiss and Alice Gavitte comes from multiple vital records. The information on Alice O'Connell comes from only two sources: Bix's pen and the funeral register in Davenport, Iowa, after Bix had passed on. It lists Alice O'Connell of New York, next to the Weiss family, among those who sent flowers. A possible, but currently unproven, explanation is that Alice chose to go by the name Alice O'Connell as a stage or professional name, and for the purpose of Bix's letter either he or Alice modified her parents' surnames and backgrounds to fit that mold. "She was connected with the entertainment field," Stephen Ickes recalled in 1972. ${ }^{19}$ There is also the question of the first name of the "Miss Weiss" cited by Bix's brother Charles and by Hoagy Carmichael in their correspondence with Phil Evans. Charles Beiderbecke refers to her simply as Miss Weiss, no first name. Hoagy Carmichael, on the other hand, remembered her as Helen, but that was nearly 30 years later, and as noted, while Alice's mother's name was Helen (nickname Nellie), and Alice had a sister named Helen, both Helens were long dead by 1931 . In any case, we know now, as demonstrated by Alice's

${ }^{19}$ Evans and Evans, Bix, 544. 
photographs, that Alice O'Connell and Alice Weiss were one and the same person. Moreover, we believe that the first name Helen for Alice Weiss/Gavitte represents a faulty recollection on the part of Hoagy (who is known not to have had the most accurate memory), or perhaps the first name of one of Bix's friends that Hoagy might have met.

Perhaps, the most difficult aspect of the O'Connell-Weiss-Gavitte puzzle relates to Alice's married name in 1931, Gavitte, and the fact that neither Bix nor Hoagy reported that Alice was married to Rex Gavitte. It does not seem possible that Bix unaware that Rex and Alice Gavitte were husband and wife. After all, it was Rex who brought Bix to his residence at $246032^{\text {nd }}$ Street in Astoria so that his wife Alice could take care of him. However, if Alice and Bix were romantically involved, it seems reasonable that he would conceal from his parents the fact that Alice was a married woman and used the name Alice O'Connell. It is interesting to note that among all of Bix's New York friends and associates with any memory of his female companion, none recalled her as Mrs. Rex Gavitte. In part, that may speak to the manner in which Bix introduced her, and/or Alice referred to herself, and may explain why she was remembered as "Miss Weiss." There is no recollection among present members of the Weiss family that Alice was married to Rex Gavitte. However, there are two photos of Rex Gavitte in the family collection of photographs.
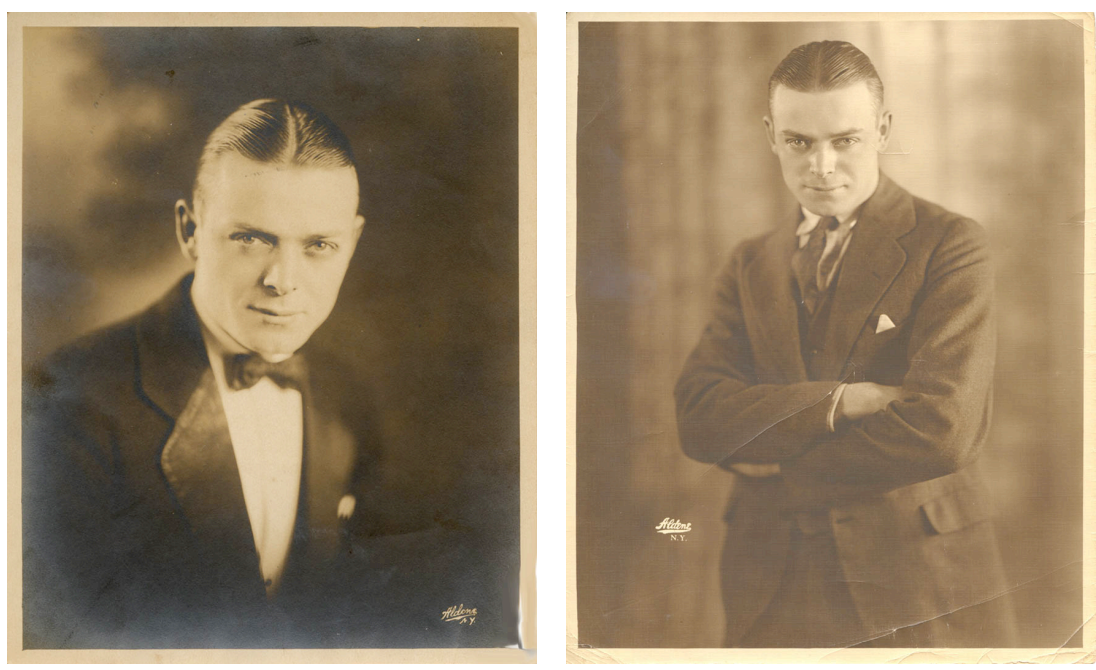

Figures 12 \& 13. Photographs of Rex Gavitte by Aldene, New York. The name Rex Gavitte is written on the back of these photographs. Courtesy of Raymond Weiss. 
It will be noted that the photographs were taken at the Aldene Studio in New York. For all of the 1920s, through 1930, the Aldene Studio was located at 1628 Broadway, on the corner of 50 ${ }^{\text {th }}$ Street in Manhattan. From 1931 through at least the mid 1930s, Aldene Theatrical Photographers was located at 1657 Broadway. By 1936 the business had moved to 152 West $42^{\text {nd }}$ Street. There are two additional photographs from Aldene, both of Alice, in the Weiss family collection of photographs.
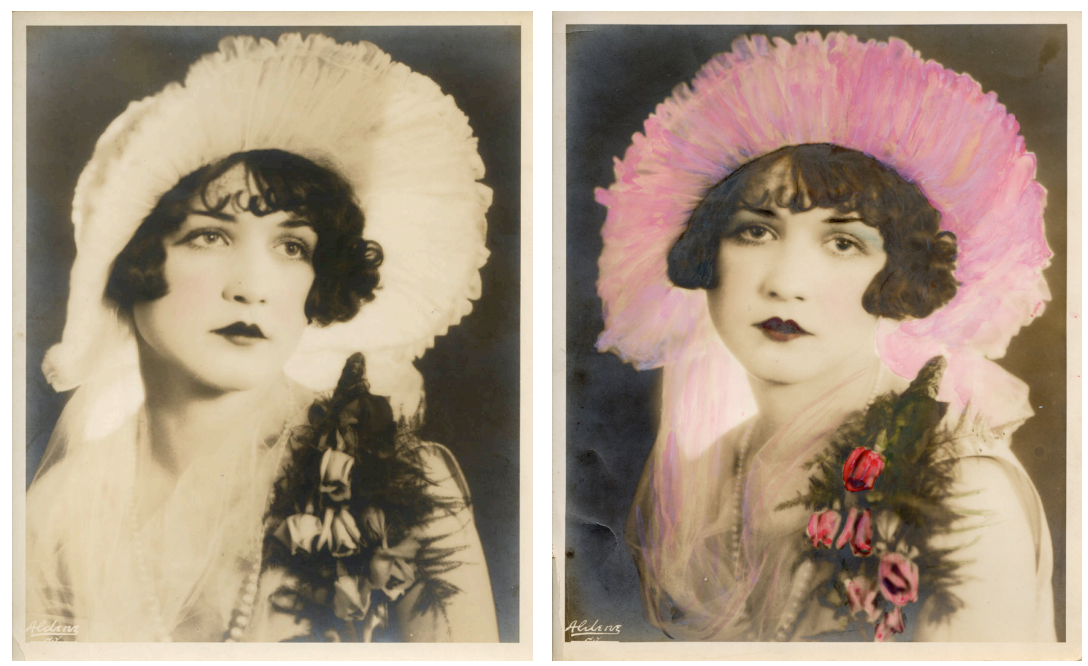

Figures $14 \& 15$. Alice Weiss by Aldene, New York. Courtesy of Raymond Weiss.

We believe that these photos were taken in the late 1920 s or very early 1930 s, before Alice and Rex were divorced.

\section{ALICE AFTER BIX}

On May 23, 1932, Alice Gavitte filed for divorce (see Appendix, Figure 16). Alice was the plaintiff and R. B. Gavitte was the defendant. The divorce decree was issued on October 20, 1932. According to New York State law, divorce records are sealed for 100 years; therefore, we do not know the details of the proceedings.

We have no information about Alice for the mid and late 1930s. In the U.S. Census of April 1940, sisters "Francis," Mary and Alice Weiss were living together at 29 Sickles Street, in the upper Manhattan neighborhood known as Washington Heights. Frances was working as a phone company clerk. Mary was employed as a telegraph clerk. Alice, age 28 (actually she was 33), single, is listed as having had two years of high school education, no current occupation, and she neither worked nor generated any income in 1939. The address is 
located in the extreme northwest end of Manhattan Island, about two blocks from Fort Tryon Park. Alice and her sisters obviously favored this neighborhood. As we will see below, one year later, Alice was living on Arden Street, one block away, and in 1946 on Seaman Avenue, less than one mile away. Frances and Mary also lived on Seaman Avenue in 1946.

We found Alice again in 1941 in connection with the death of her exhusband. Rex Gavitte continued jobbing around New York City. For the years 1930-1932, the Local 802 annual directories list his address as 2460 32nd St., Astoria, L.I., the temporary address Bix had given in his June 16, 1931 letter to his parents. In 1933, the year following his divorce from Alice, Rex was living at the Endicott Hotel, 81st St. and Columbus Ave. In 1935 Rex's residence was 262 West $52^{\text {nd }}$ Street. The June 22, 1935, issue of the New York Times reported that Rex Gavitte's band was playing at Place Elegante in Manhattan. From the Brooklyn Daily Eagle, August 14, 1936: "Rex Gavitte, comedy musician, has been added to the new Summer show at the Place Elegante, 33 W.56th St. Gavitte offers a series of musical novelties on several different instruments." The Place Elegante, located in what had been the town house of James P. Donahue-Donahue was married to Jessie Woolworth, heiress to the fortune of the founder of the 5 and 10 store-was a speakeasy and gambling establishment during prohibition, and became a high-class restaurant in the 1930s.

According to the 1940 U.S. Census, Rex Gavitte was living at 150 West $66^{\text {th }}$ Street, borough of Manhattan in the household headed by Helen Marlowe, age 29, occupation waitress in a restaurant for 33 weeks. Also in the home were Helen's daughter Dorothy, age 11, and son Eugene, age 10, both in school. Rex Gavitte is listed as a lodger, age 39, musician with an orchestra, for 56 weeks.

Rex Gavitte died in Bellevue Hospital in Manhattan on December 18, 1941, from: "Bronchopneumonia; Chronic alcoholism; Old contusion of brain surface; Accidental fall while intoxicated 10/30/41 at unknown location." As seen in the death certificate (see Appendix, Figures 17A-B), Rex is described as divorced, husband of Alice. However, although the informant - the person who provided information about the decedent such as full name, date of birth, place of birth, last address, etc. — was Rex's ex-wife Alice Weiss, she identified herself as a "friend" and was acting on behalf of Rex's mother, Sara Hoggins [sic] of St. Petersburg, Florida. Sarah, née Richards, had remarried and taken up the name Higgins. Rex Gavitte was buried in a single grave, St. Peter Section, Grave \#: 1087 in Ferncliff Cemetery, Westchester County. Some notable people buried in that cemetery are Judy Garland, Joan Crawford, Bela 
Bartok, Yul Brynner, Annette Hanshaw, Paul Robeson, Harold Arlen, Cab Calloway, Moss Hart, Ed Sullivan, and John Lennon.

So Alice, who had dealt with the tragic death of Bix ten years earlier, handled the arrangements for her ex-husband, Bix's benefactor. At this time, Alice was living at 100 Arden Street, in the upper Manhattan neighborhood known as Washington Heights.

A few months later, on February 14, 1942, Alice married Max Weiss, who had, at least a decade earlier, changed his name from Schnapper to Weiss.

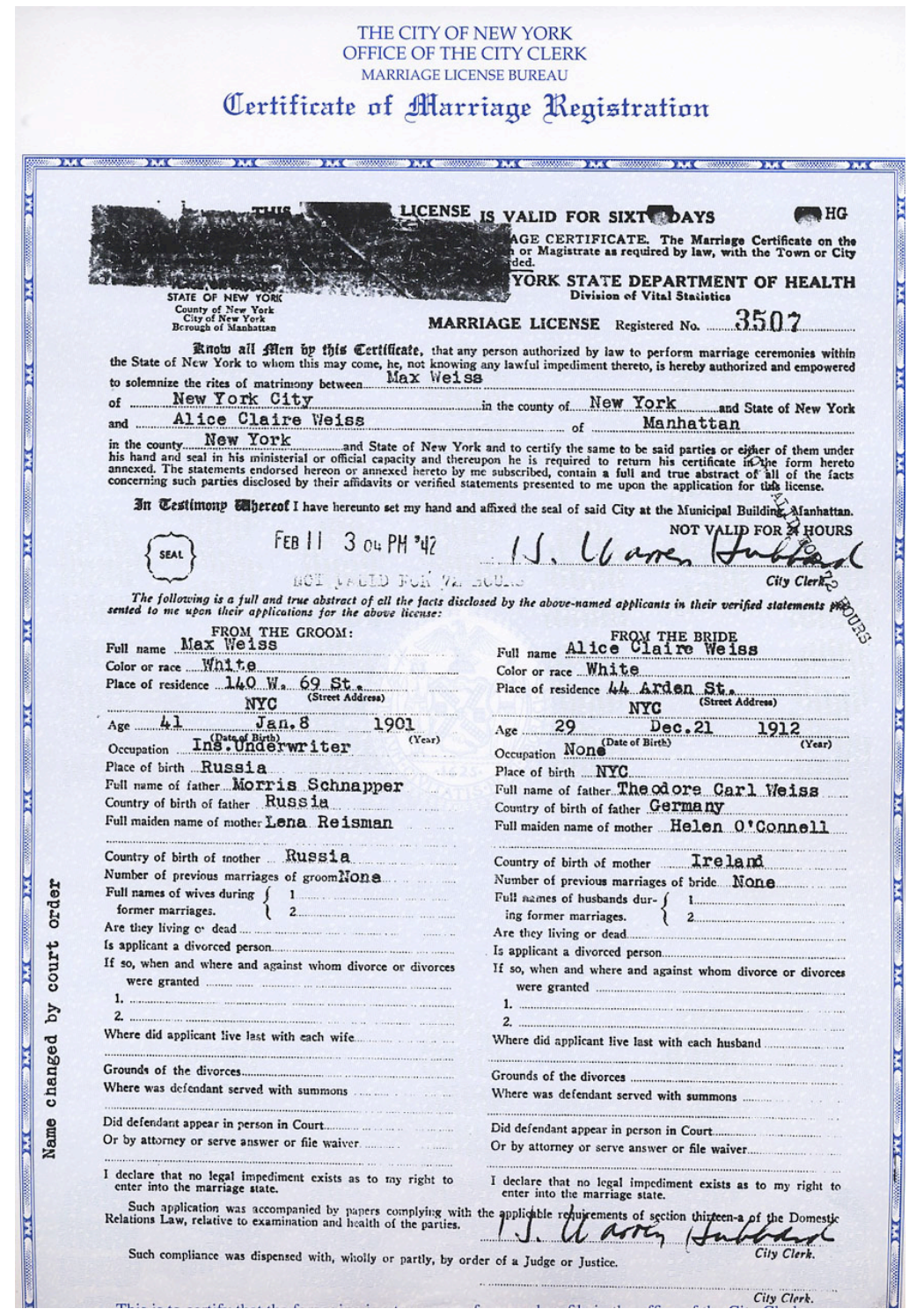

Figures 18A. Certificate of Marriage Registration, page 1. Alice Weiss and Max Weiss. 


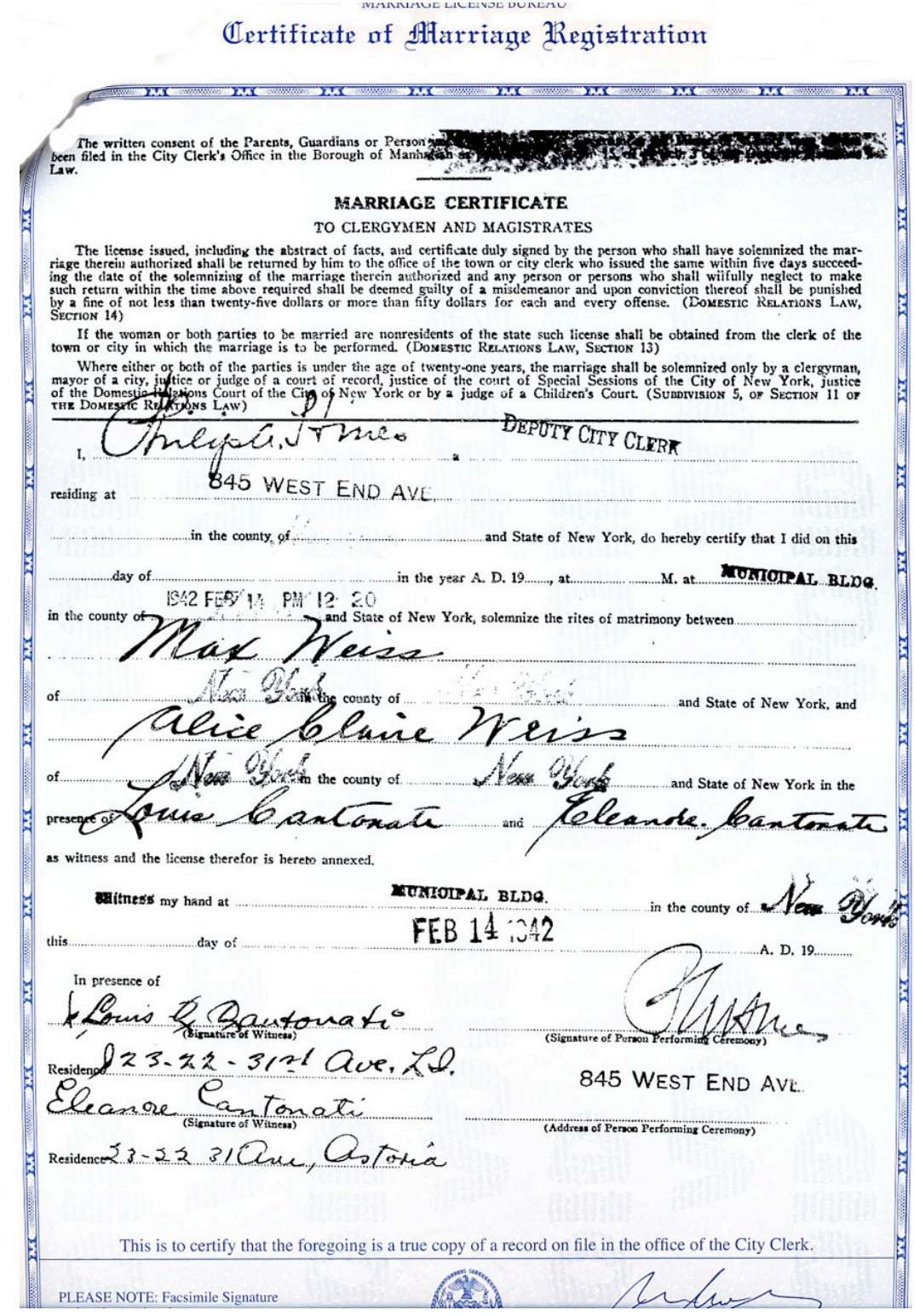

Figures 18B. Certificate of Marriage Registration, page 2. Alice Weiss and Max Weiss.

Max Weiss was born on January 8, 1901 in Odessa, Russia. According to his certificate of arrival (see Appendix, Figure 19), Max arrived in the United States on November 8, 1906 on the S.S. Teutonic. However, according to Manifests of Alien Passengers, Matel Schnapper, age 5, and his mother Lise or Line Schnapper, both from Odessa, Russia left Liverpool, England on September 5, 1906 and arrived on September 13, 1906 aboard the S.S. Teutonic. Note that Max, in his Certificate of Marriage Registration to Alice, 
gives his mother's name as Lena. In his declaration of Intention for naturalization (see Appendix, Figure 20), Max Weiss stated that he married Laura Helig on August 17, 1932. The certificate of marriage (Appendix, Figure 21) gives August 19, 1932. Thus, Max had changed his last name from Schnapper to Weiss at least nine years before his marriage to Alice. Laura Heilig immigrated to the United States in 1930. She was born in 1911 in Pfullendorf, Germany, left Hamburg on February 28, 1930 and arrived in New York on March 10, 1930. On July 3, 1941, Max's petition for naturalization was approved (Appendix, Figures 22A-B). It will be seen that one of the witnesses was none other than Alice Weiss.

It is noteworthy that in their Certificate of Marriage Registration, both Alice and Max stated that they had not been married previously, when, in fact, they had. It is likely that Max's first marriage ended in divorce. According to the index of NY County Supreme Court cases, there is a filing by plaintiff Laura Weiss against Max Weiss in 1936.

In her marriage certificate to Max Weiss, Alice gave her middle name as Claire and her date of birth as December 21, 1912. In fact, Alice was born on December 21, 1906 and her middle name was Regina. It turns out that Alice, for reasons unknown to us, was using Claire as her middle name. This is demonstrated in her application for a Social Security number where she gives Alice Claire Weiss as the name she would use at work and Alice Regina Weiss as the name given to her at birth.

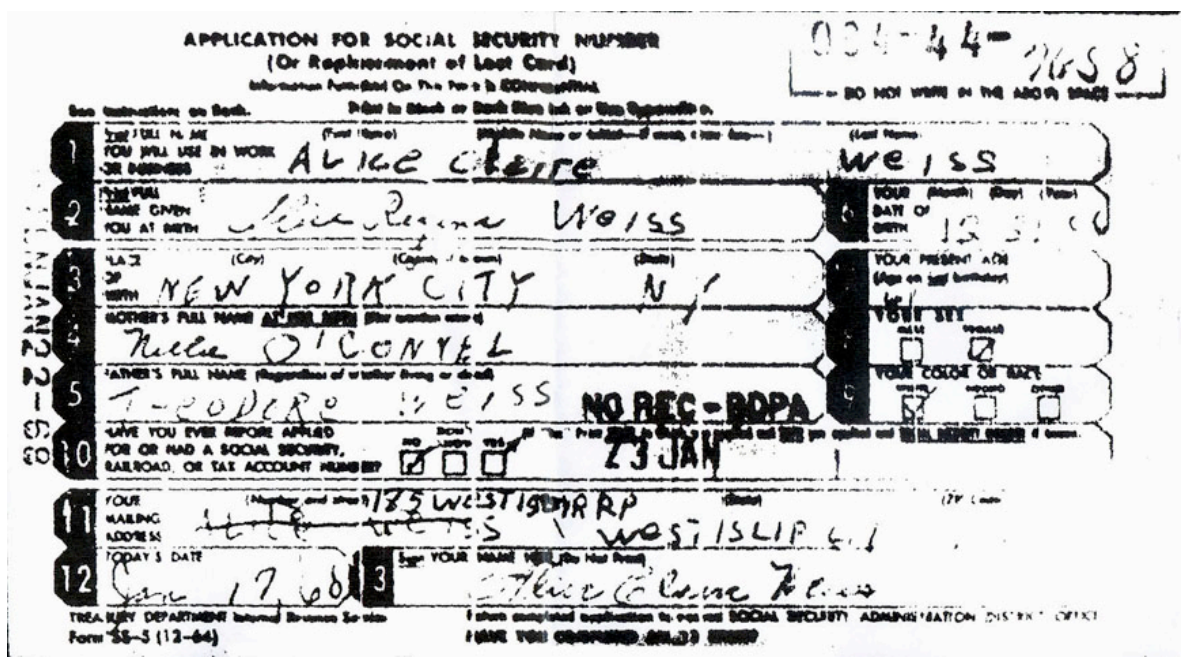

Figure 23. Application for Social Security Number Alice Weiss 
Alice and Max had known each other since at least 1940. Here is a painting of Alice by Max Weiss dated May 1, 1940:
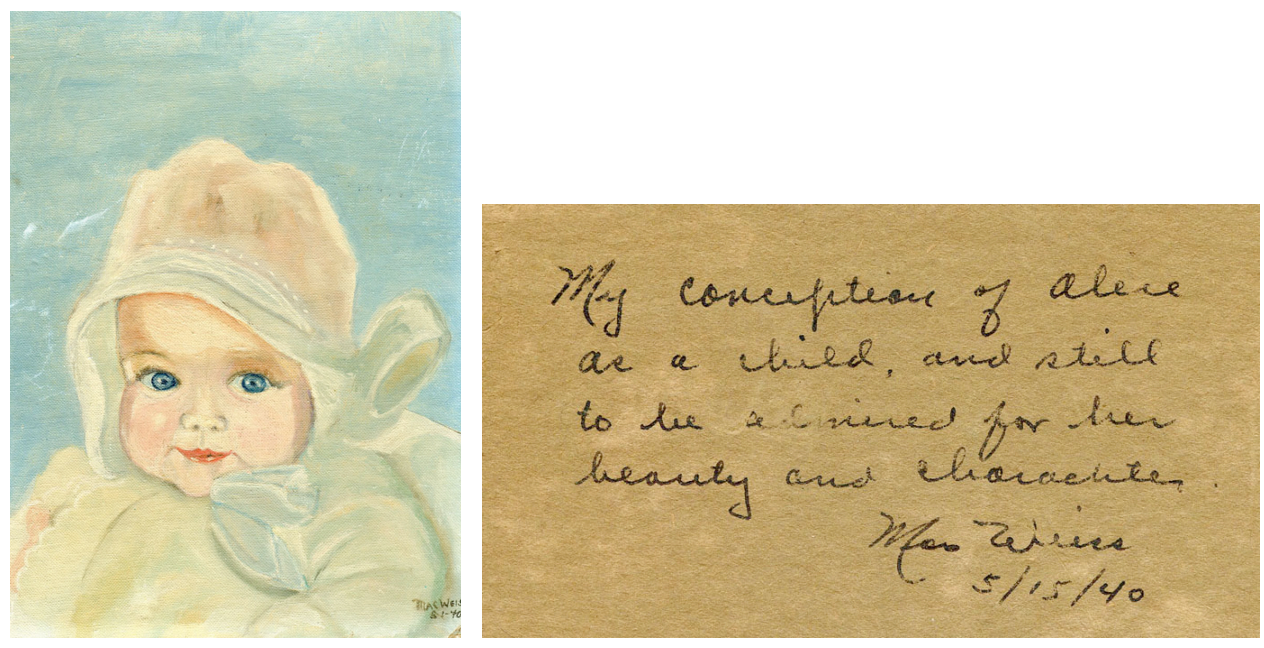

Figure $24 \& 25$. Artist's Conception of Alice as a Baby and the back of the painting. Courtesy Douglas Weiss.

Obviously, Max was deeply in love with Alice, and less than two years later, married her.

The 1946 New York City telephone directory gave the address of Max and Alice as 145 Seaman Avenue, an apartment building in the Inwood neighborhood, a section of New York City with a substantial Irish and Jewish population in the first half of the $20^{\text {th }}$ century. Max's insurance business address was 200 Fifth Avenue in Manhattan, an office building known as the Toy Center Building, constructed in 1909 in what had been the location of the luxurious Fifth Avenue Hotel.

In November 1956, Alice and Max Weiss purchased the property at 185 West Islip Road, West Islip, NY, an upscale hamlet (average family income in 2009 was over $\$ 100,000)$ in the south shore of Long Island with easy access to the Great South Bay and Fire Island (see Appendix, Figure 27). In 2008, at the height of the housing bubble, the property, with a new house having replaced the original house, was valued at over $\$ 1,000,000$. 


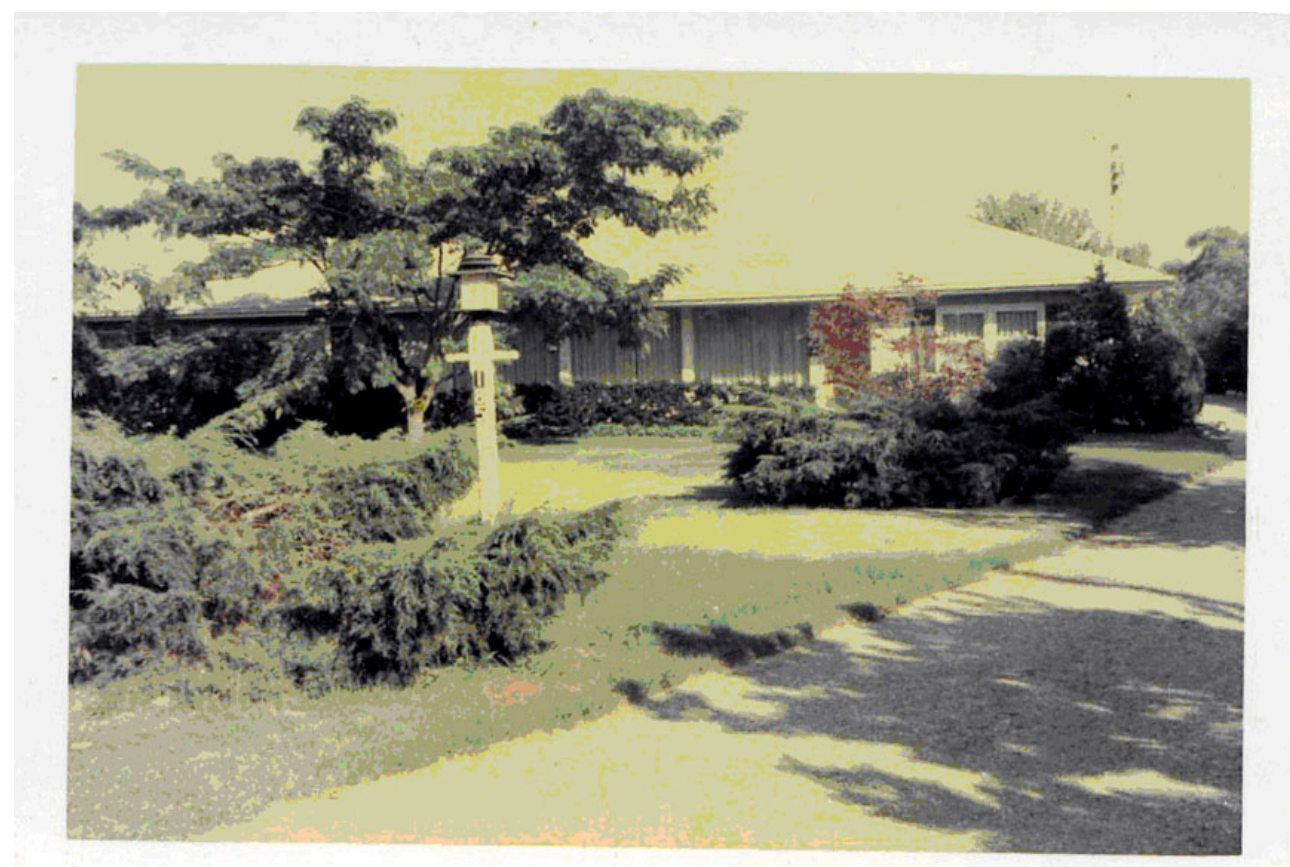

Figure 26. Original House at 185 West Islip Road West Islip, New York

It is perhaps surprising that Alice decided to move to the suburbs. Apparently, she was a confirmed New Yorker. In the letter to his parents, Bix writes about Alice, "born in New York never been out you should hear her accent." In an October 19, 1949, letter to his wife Veronica, Alice's younger sister, Philip Monaghan writes, "Hope Alice was the right kind of help when she went to Jersey with my baby. You see, Alice thinks that living in Jersey or anyplace away from the crowds of N.Y. is something that shouldn't happen to a dog." Nevertheless, Alice seems to have adapted nicely to life in suburbia. The house in West Islip was ideal for family gatherings. 


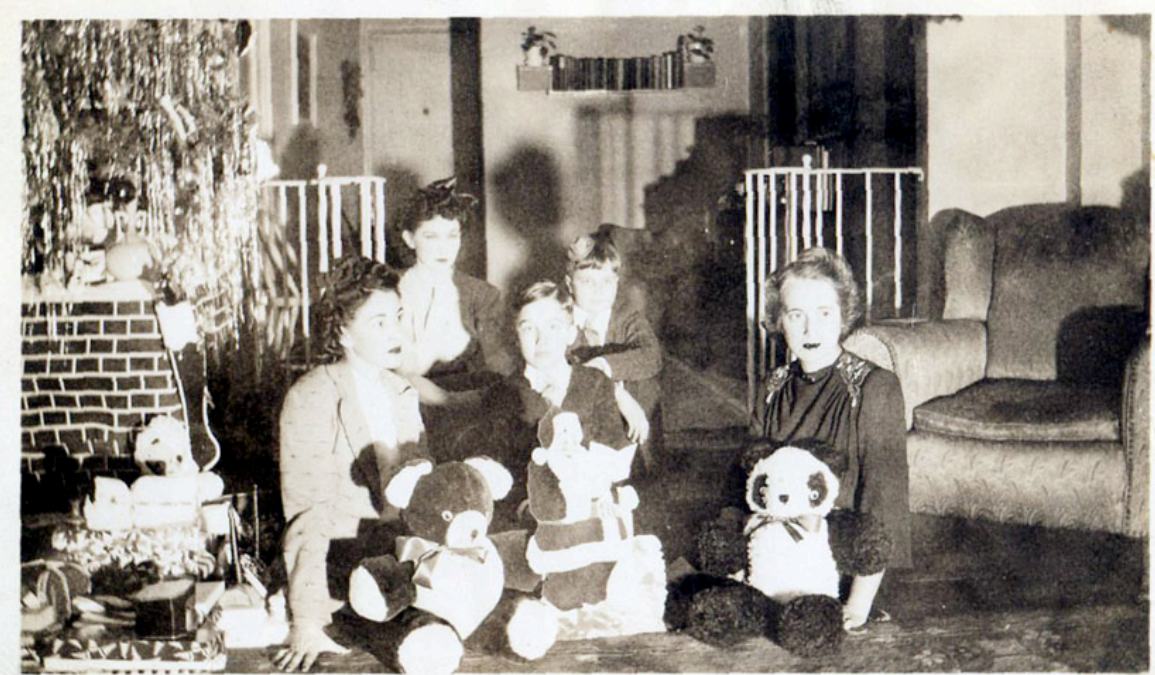

Figure 28. West Islip Home. Left to Right. Front: Alice Weiss, Ronald, Margaret. Back: Frances, Raymond. Courtesy Douglas Weiss.

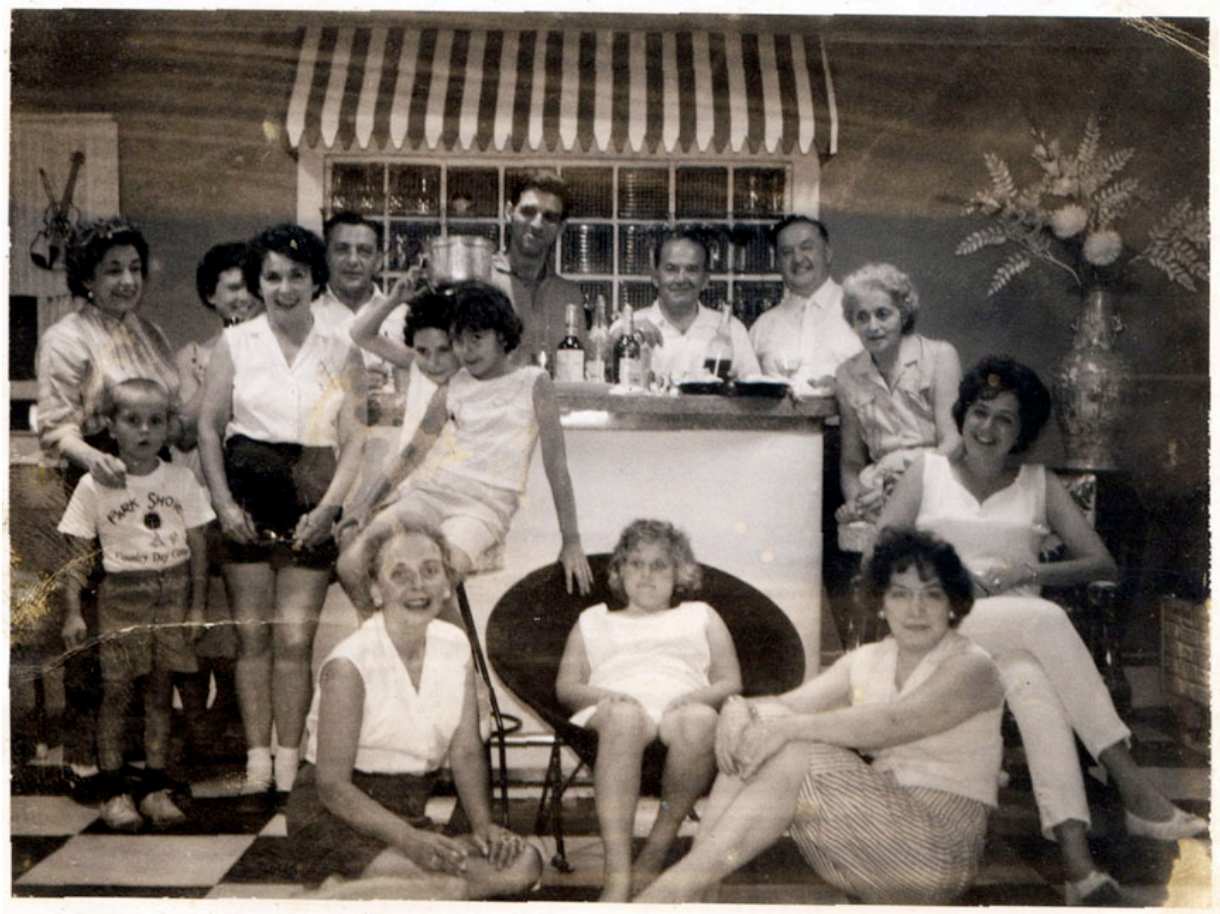

Figure 29. Members of the Weiss Family in The West Islip Home. Alice, front right. Courtesy Of Patricia Weiss 
Alice's siblings, nephews, and nieces would visit her on weekends and Max would take them out on his boat, typically docked in the canal in the back of the house, to the Great South Bay.

In the 1960s, Alice became a serious participant in several Long Island Kennel Club Shows and won several awards for her poodles.
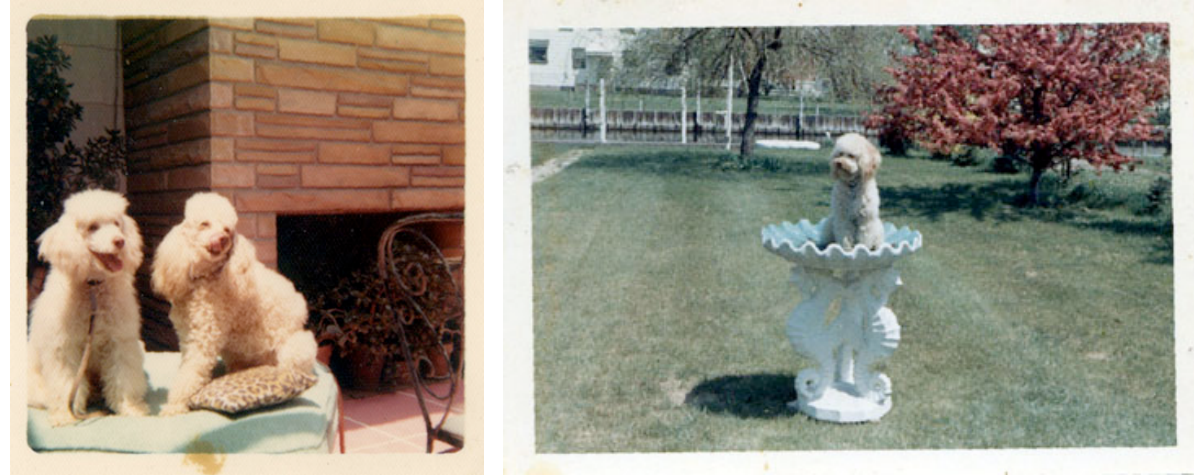

Figures 30 \& 31. Alice's Poodles. Courtesy of Patricia and Douglas Weiss.

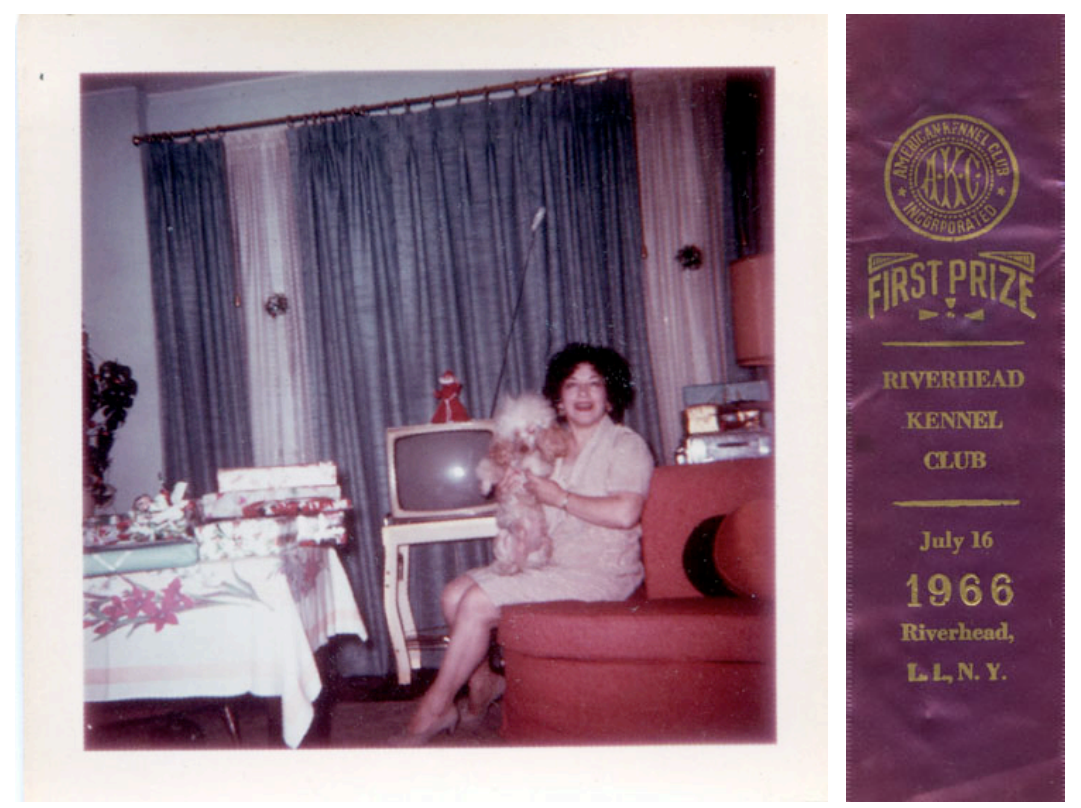

Figures 32 \& 33. Alice with One of Her Poodles and First Prize Ribbon. Courtesy of Patricia Weiss

Max Weiss died in 1967. A short announcement was published in the Babylon Beacon of January 11, 1968. "Max Weiss of 185 West Islip Rd. W. Islip, passed away on December 24, 1967 at the age of 66. Mr. Weiss is survived by his wife Alice. He reposed at the Chapey Funeral Home until 
Wednesday when religious services were conducted by Rabbi Leon Speilman. Interment was in Mt. Ararat Cemetery, Pinelawn, N.Y."

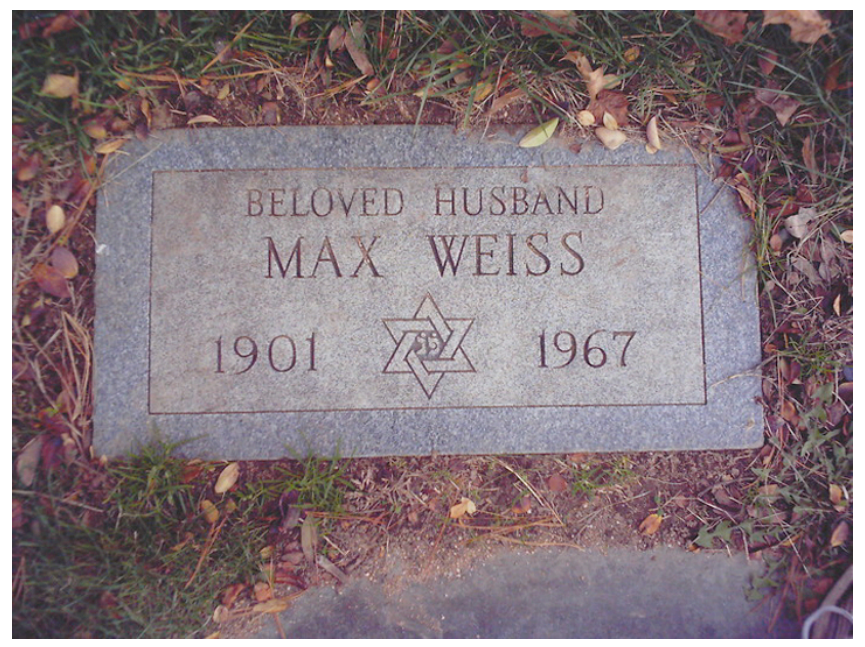

Figure 34. Max Weiss Stone, Mount Ararat Cemetery Suffolk County New York, USA Plot: Section 86, Range E, Lot 42.

In his last will and testament dated August 8, 1947, Max Weiss specified: "I hereby give, devise and bequest all of my estate, real personal and mixed and wheresoever situated, of which I may die seized or possessed, to my wife, Alice Weiss. In the event that my said wife predeceases me ... I hereby give, devise and bequest all of the property of which I may die seized or possessed to my wife's sister Frances Weiss.”

It turns out that all of Alice's older sisters died before she did. As mentioned, Lillian and Florence died in the 1910s, and Mary ${ }^{20}$ and Frances ${ }^{21}$ passed away in the 1970 s.

\footnotetext{
${ }^{20}$ From the Babylon Beacon, October 28, 1971: "MARY W. J. WEISS of 121 Seaman Avenue, Manhattan, passed away on Thursday October 14, 1971 at the age of 73 years. Miss Weiss is survived by three sisters-Frances Weiss of New York, Alice of West Islip, L.I. and Veronica Monaghan and two brothers Raymond and Fred. She reposed at the Fredrick J. Chapey Funeral Home until Tuesday when a Mass of the Resurrection was offered at Saint Joseph's R.C. Church, Babylon. Interment was in the family plot in Calvary Cemetery, L.I. City, Queens, New York."

${ }^{21}$ Frances Nora died a year after Mary. From the Babylon Beacon, June 15, 1972: "FRANCIS [sic] WEISS of Manhattan, New York, died suddenly on Thursday June 1, 1972. Miss Weiss is survived by her sisters: Alice Weiss of West Islip, L.I. and Veronica Monaghan and two brothers: Raymond Weiss and Fred Weiss. She reposed at the Fredrick J. Chapey Funeral Home until Monday, when a Mass of the Resurrection was offered at Saint Joseph's R.C. Church, Babylon, L.I. Interment was in the family plot in Calvary Cemetery, Long Island City, Queens, New York."
} 
Evidently, the sisters were close to each other as demonstrated by several facts. First, Alice, Mary, and Frances lived together before Alice married Max Weiss. Second, after Alice was married to Max, Mary and Frances lived across the street from Alice's last address in New York. Third, both Mary and Frances resided in Manhattan at the time they died, but reposed at the Fredrick J. Chapey Funeral Home located at 1225 Montauk Highway, West Islip, NY, about a mile from Alice's residence on West Islip Road.

After Max died, Alice continued living in her home on West Islip Road, but, according to reports from the family, she led a very private life, except for her sisters who visited her regularly. Alice died on November 23, 1982.

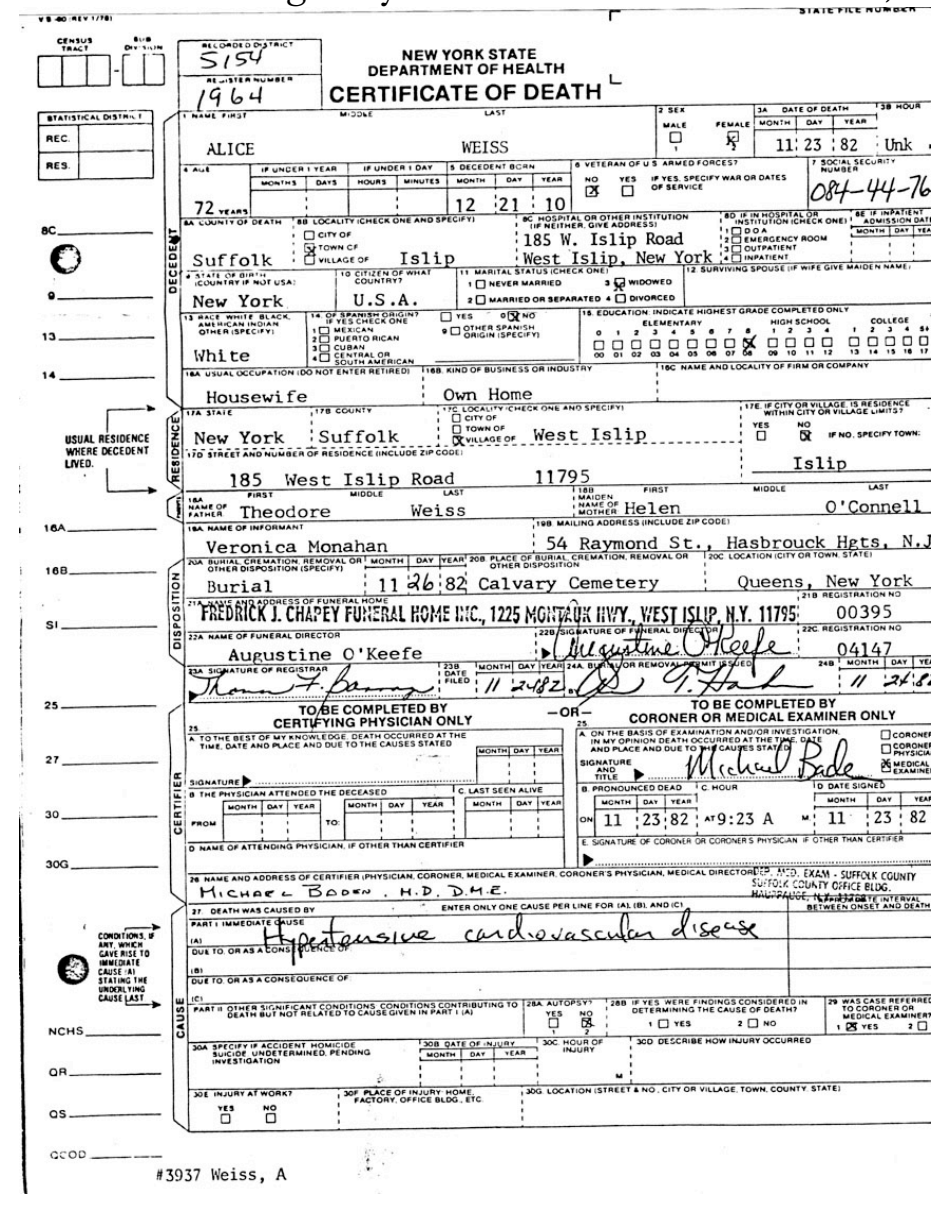

Figures 35. Death Certificate, Alice Weiss.

From the Babylon Beacon, December 2, 1982: "Alice Weiss, of West Islip, N.Y. passed away on November 23, 1982, at the age of 71 (she was almost 76). She is survived by her sister Veronica Monahan [sic] of New Jersey and her brother Frederick of Florida. Mrs. Weiss reposed at the Frederick J. Chapey 
Funeral Home until Friday, November 26, 1982 when the Celebration of the Liturgy of Christian Burial was offered at Our Lady of Lourdes R.C. Church, West Islip. Interment Calvary Cemetery, Queens, New York." Alice is buried in the Third section of Calvary, between Queens Blvd. and Laurel Hill Blvd, Section 18, Range 20, Plot Y, Grave 1. The plot was purchased on July 11, 1895 by Alice's grandfather Philip O'Connell after her baby sister Helen died. Chris Barry could find no stone marker for that plot when he visited on February 15, 2012.

In her last will and testament dated May 31, 1966, Alice left her estate to her sister Frances Weiss of 121 Seaman Avenue of New York City, provided she survived Alice. Then, Alice specifies, "If said Frances Weiss predeceases me then I give and bequeath said residuary estate to my sister, Veronica Monaghan, also known as Vera Monaghan, of 54 Raymond Street, Hasbrouck Heights, New Jersey." Since Frances died in 1972, eleven years before Alice, her younger sister Veronica, the only one of her sisters to survive her, inherited the house on West Islip Road. Veronica was married to Philip Monaghan and lived in New Jersey. She would go to West Islip periodically, particularly during the summer. The rear of the property abuts a canal connected to the Great South Bay, a wonderful area for sailing and summer recreation. Here is a view of the property.

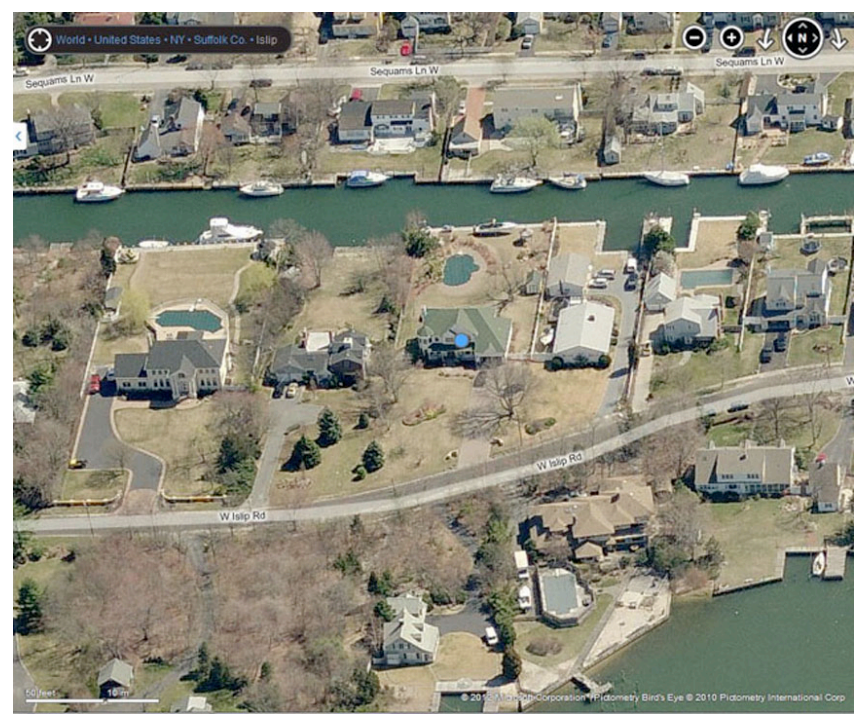

Figure 36. Property at 185 Islip Road Marked with Blue Dot. Courtesy of Bing maps

Veronica died on February 24, 1995. In her last will and testament dated January 13, 1983, Veronica left her estate to her brothers, sister in law, and 
nieces. Her niece Joan Fabrizio was the executrix of the estate and had the help of Patricia Weiss. Among the items in the house in West Islip were letters, photographs, and the piano Bix had in his apartment in Sunnyside. Sadly, if there were any papers and photographs with specific mentions of Bix, they were not kept. The house on West Islip Road was sold. In the 1990s the house changed ownership twice. Approximately 10 years ago, the current owner demolished the original house and built a new house on the property. The new house is the one marked with the blue dot in the satellite view above of West Islip Road (Figure 36).

\section{EPILOGUE}

On the basis of the information outlined in several biographical sources about Bix's final weeks and the documentation that we have uncovered, it has become evident that the woman who was known in the Bix Beiderbecke literature as either Alice O'Connell or Helen Weiss was, in fact, Alice Weiss, 1906-1982, daughter of Theodore Weiss and Helen "Nellie" O'Connell. Alice was married to Rex Gavitte in 1926-1932 and to Max Weiss in 1941-1967.

There is strong evidence that Alice and Bix were more than just casual friends brought together by Rex Gavitte's concern about Bix's health. Bix wrote to his parents in June 1931 "now about my future wife" and shows his concern that Alice was Catholic. Bix also wrote to one of his best friends in Davenport, Esten Spurrier, that "at last he had fallen in love." In July 1931, Bix and his girlfriend, identified by Hoagy Carmichael as Helen Weiss, visited Hoagy in his apartment in New York City. In his letter to the New Orleans Museum (reproduced in its entirety above) Hoagy wrote, "They (Bix and Miss Weiss) had been dating for some weeks. In fact they visited me in my apartment just a week before his illness. She sent these articles to me a few days after his death.” In letters dated February 10 \& 21, 1967, Bix's brother Charles told Phil Evans, "I am quite certain, too, that Miss Weiss had made all the arrangements to have Bix's body shown. It was my mother's impression as well as mine that Bix was engaged to Miss Weiss." Marie Louise Shoemaker, Bix's sister, when interviewed by Joe Giordano told him she "... received a letter from him (Bix) stating that he had become engaged to be married."22

Joan Fabrizio, the former Joan Weiss (Alice's niece), told Albert Haim in a telephone conversation dated February 10, 2012, that the Weiss family viewed Bix and Alice as a couple. When the Warner Bros. film Young Man With A Horn (loosely based on Bix Beiderbecke's music and life) was released

\footnotetext{
${ }^{22}$ Joseph J. Giordano, unpublished notes to become part of his biography of Bix Beiderbecke.
} 
in 1950, Joan and her mother went to see it and tried to identify which of the actresses in the film was playing the role of Alice.

Alice Kimble (née Weiss) another of Alice's nieces, wrote to Albert Haim on February 7, 2012: "It was known in the family that Alice had some sort of special relationship with Bix but no real details were disclosed."

Alice knew Bix for a relatively short time, yet his name still resonates with family members. Meanwhile, although Alice was married to Rex Gavitte for six years, and knew him for at least 15 years, he registers barely a blip in the collective memory of the Weiss family. It seems that the relationship between Alice and Bix was serious and it is quite possible that they were planning on getting married. Possibly, by 1931 Alice and Rex had already decided their union was nearing an end, as demonstrated by their divorce the following year and the fact that the 1930 U.S. Census for the borough of Queens has Alice Gavitte as head of the household and sister Vera Weiss living at 2460 32nd Street, and no mention whatsoever of Rex Gavitte. One significant piece of evidence in establishing a close relationship between Alice and Bix is the finding of a photograph of the Jean Goldkette orchestra among the collection of family photographs.

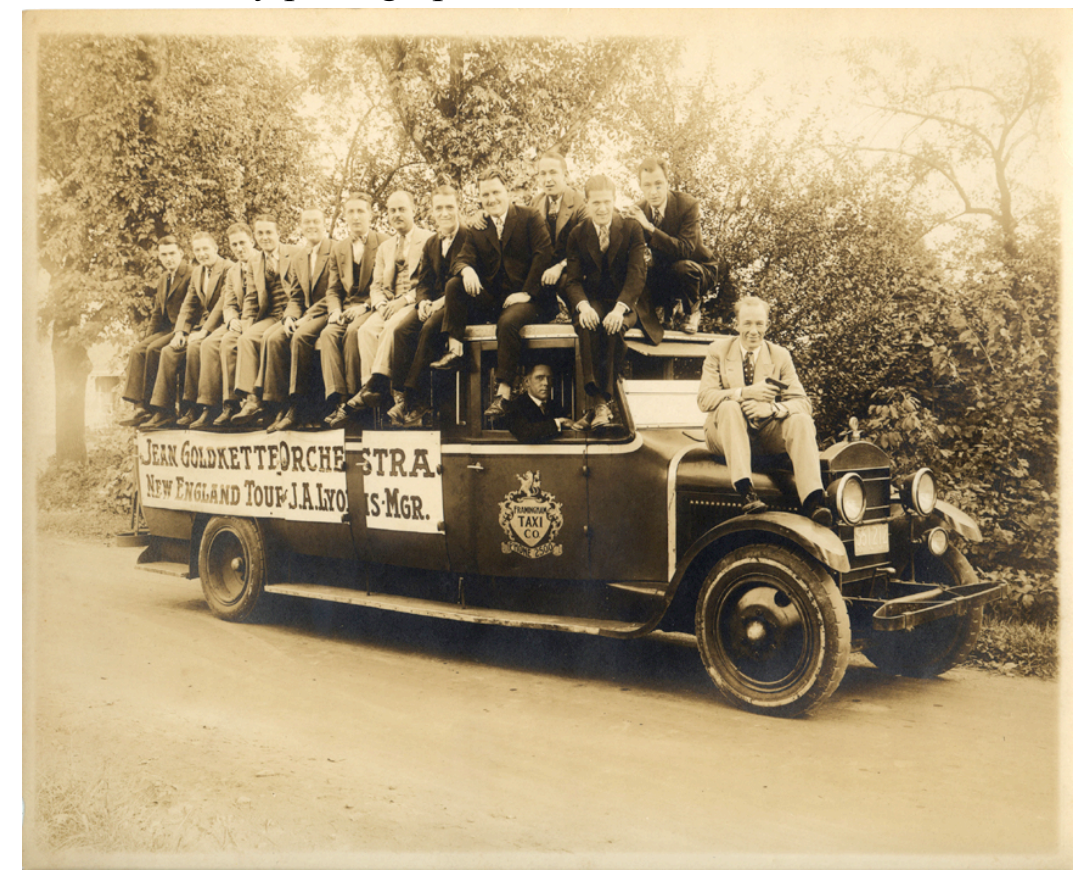

Figure 37. Jean Goldkette Orchestra in 1926. Courtesy of Raymond Weiss.

This photograph is an original photograph, not a copy. We believe this fact to be highly significant: it provides evidence for a close relationship between Alice and Bix. How else would an original photograph of the Jean Goldkette 
Orchestra be found in the Weiss family collection of photographs? In addition, the Bix Beiderbecke issue of Metronome magazine (November 1938) was also part of Raymond Weiss's collection of family memorabilia.

On the other hand, amid illness and fewer job prospects, Bix may have viewed Alice as the one glimmer of sunshine in his world, and from that blossomed an infatuation with her, married or not. However, there is no evidence that Alice assented to, or even knew of, Bix's nuptial plans. Bix may have wished to marry Alice, but we do not know if he proposed or if Alice remained a dear friend and a "secret passion," or just a dear friend. It is also unclear where Rex Gavitte stood in all this. Did he know or care about what was going on, or was there nothing going on to begin with? We also do not know to what extent Bix's written thoughts were fueled by love, or alcohol. It is possible Bix drew more upon fantasy in his last letters home in order to put a positive spin on his unraveling life for his parents.

Regardless of whether marriage was in the horizon or not, it seems clear that Alice was the closest person to Bix during the last few weeks of his life. When Bix died, Alice made all necessary arrangements and took charge of dispersing Bix's personal property: the cornet and some personal items went to Agatha, Bix's mother; Alice gave to Hoagy Carmichael Bix's cuff links, a pair of handkerchiefs and a cornet mouthpiece; Alice kept Bix's piano for herself.

\section{CODA: BIX'S PIANO}

The presence of a piano in Bix's apartment in Sunnyside is well documented. In 1931, Bix wrote to his close friend Esten Spurrier, "that he had bought a piano, and was very seriously playing and noodling around and expected to come up with some piano compositions." ${ }^{23}$ On April 8, 1959, rental agent George Kraslow wrote to Phil Evans: "A few people living in the apartment house complained to me, half-heartedly, about someone playing the piano at 2:00 a.m. It wasn't until then I discovered Bix worked on musical compositions during the wee hours of the morning." ${ }^{24}$ Joe Giordano interviewed Mary Beiderbecke, Bix's sister in law, in 1976. ${ }^{25}$ Mary told Joe: "They (Bix's mother Agatha and brother Burnie) discovered that a wake was being held for Bix. They saw flowers and candles around the coffin since Bix had taken instructions in the Catholic Faith in preparation for his marriage to Alice. The only things taken back to Davenport were the body, the horn, and a few miscellaneous items; the piano was left behind."

\footnotetext{
${ }^{23}$ Sudhalter and Evans, Bix, 327.

${ }^{24}$ Evans and Evans, Bix, 544-545.

${ }^{25}$ Joseph J. Giordano, unpublished notes to become part of his biography of Bix Beiderbecke.
} 
There is strong evidence that Alice took possession of Bix's piano when Bix died. Bix's sister Mary Louise told Malcolm Bessom "towards the end, Bix was engaged to be married" and that "after Bix died the Beiderbeckes gave his fiance [sic] his grand piano." ${ }^{26}$ Bix's brother Charles "Burnie" Beiderbecke stated "I'm sure that we were told that Bix wanted Miss Weiss to have his Weber piano. It is, however, still in our family." ${ }^{27}$ Burnie's recollection is, in part, faulty. Indeed, the Beiderbecke family owned a 1924 Weber grand piano, serial number 78442, purchased in 1925 or 1926 from the Arthur P. Briggs Company of Davenport (see Appendix, Figure 38).

This piano was in continuous custody of the Beiderbecke family from 1925-26 until 1991, when Charles "Chuck" Beiderbecke, Bix's nephew, who had taken possession of the piano in 1952, donated it to the Putnam Museum in Davenport. The travels of the Weber piano from Bix's home on Grand Avenue to the Putnam Museum are documented in detail. ${ }^{28}$ Thus, the piano that Bix had in Sunnyside was not the Weber Beiderbecke family piano.

The piano was not Pat Ciricillo's Wurlitzer upright either. In a letter to Philip Evans dated February 21, 1976 Pasquale "Pat" Ciricillo wrote: "For the month of July [1931] I was in Italy and Bix rented my piano." ${ }^{29}$ Pat Ciricillo was a musician who lived in the 44th Street Hotel from September 1929 to June 1930 and from September 1930 to June 1931. ${ }^{30}$ He was Bix's next-door neighbor in the hotel: Bix lived in room 605 and Pat in room 606. Pat had a Wurlitzer upright piano in his room which Bix used to compose and play for friends who visited him. Pat offered to sell the piano to Joe Giordano, but Joe declined because at the time he was living in a small apartment in New York City and had no room for the piano. The piano was sold to Frank and Connie Smith who donated it to the Louisiana State Museum in 1987.

\footnotetext{
${ }^{26}$ Malcolm E. Bessom, "The Davenport Legend: Bix Beiderbecke," Jazz, 5, Nol. 3 (1966), 25.

${ }^{27}$ Sudhalter and Evans, Bix, 334.

${ }^{28}$ Albert Haim, "Imagining 7ths and 9ths: Bix Beiderbecke's Compositions for Piano, LAJRC Journal, 43, no. 1 (2010), 10.

${ }^{29}$ Evans and Evans, Bix, 544.

${ }^{30}$ Ciricillo played trumpet and occasionally substituted for Bix in the Camel Pleasure Hour.
} 


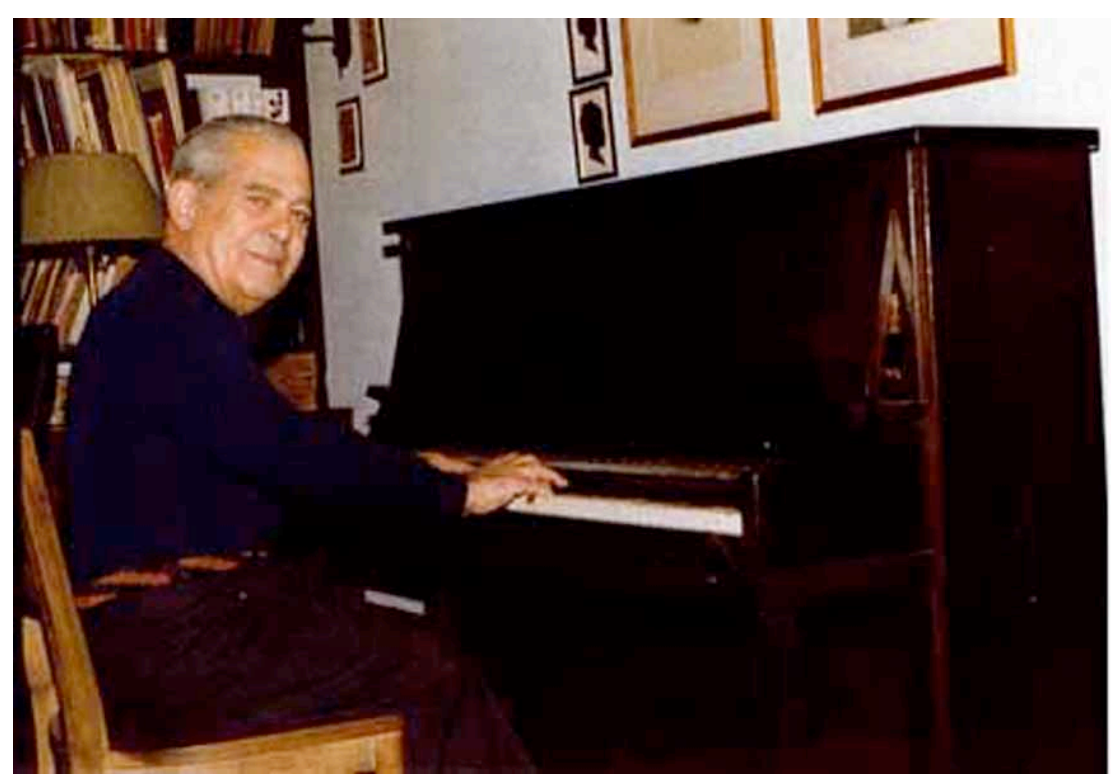

Figure 39. Pat Ciricillo and his Wurlitzer Piano, late 1960s. Courtesy Joe Giordano.

It turns out that Pat Ciricillo's recollection of renting his piano to Bix in July 1931 is very likely faulty. Another section of Ciricillo's letter to Phil Evans was transcribed in Phil and Linda Evans' Bix biography: "Bix wrote his last two piano compositions, 'Flashes' and 'In the Dark' earlier in the year (1931)."31 Indeed, Bix copyrighted the two pieces on April 18, 1931. However, Evans' transcription of that portion of the letter has been altered. The complete letter from Ciricillo to Evans was published. ${ }^{32}$ A scan of the letter is reproduced here.

\footnotetext{
${ }^{31}$ Evans and Evans, Bix, 544.

${ }^{32}$ Albert Haim, "Imagining 7ths and 9ths: Bix Beiderbecke's Compositions for Piano, LAJRC Journal, 43, no. 1 (2010), 10.
} 
February 21, 1973

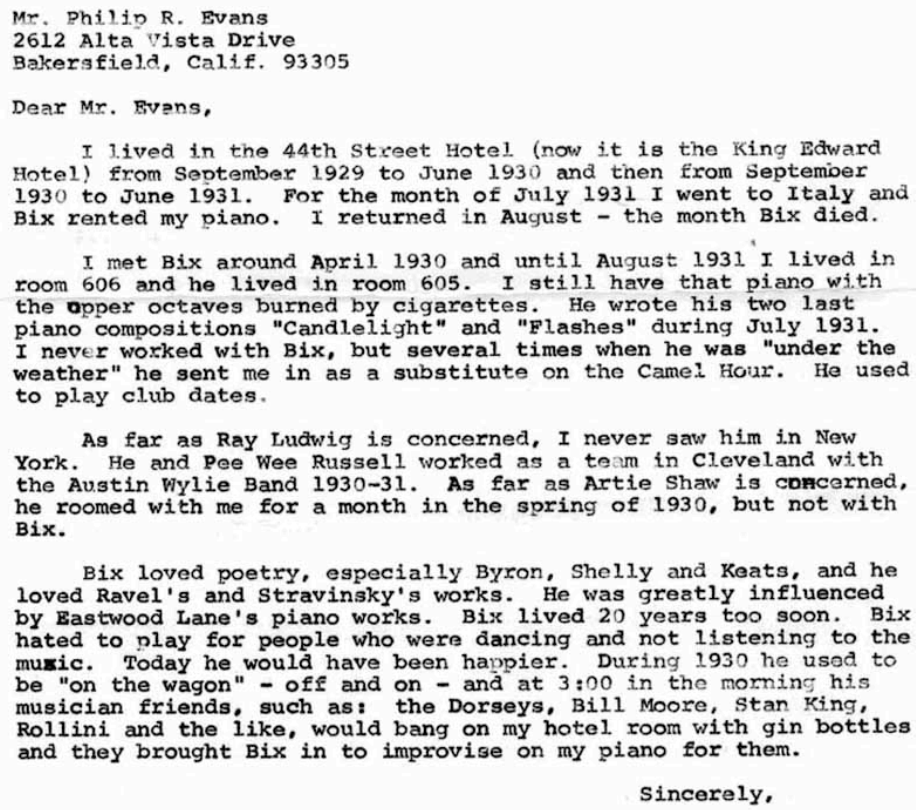

Figure 40. Letter from Pat Ciricillo to Phil Evans. Courtesy of Robert Ciricillo, Pat's son.

It will be seen that the original letter read as follows, "He (Bix) wrote his two last compositions 'Candlelight' and 'Flashes' during July 1931." Phil Evans made two alterations: the title of one of the compositions ("In the Dark" instead of "Candlelight") and the date they were composed (earlier in the year instead of July 1931). As a matter of fact, "Candlelight" was copyrighted on Aug 29, 1930 and "Flashes" on April 18, 1931; these pieces were not written in July 1931 as stated by Ciricillo. Thus, Pat Ciricillo's recollection of dates and titles for the compositions was faulty. There is another alteration of Ciricillo's letter in Evans' transcription. From Evans and Evans, "The piano was returned to me (Pat Ciricillo) in August, the month Bix died." The original letter reads, "I returned in August the month Bix died." Indeed, Pat Ciricillo sailed from Naples, Italy on July 25, 1931 aboard the S.S. "Conte Grande" and arrived in New York on August 3, 1931, three days before Bix died. We know from Mary Beiderbecke's (Bix's sister in law) testimony that Bix's piano was still in his apartment on August 7, 1931 when Bix's mother and brother arrived in Sunnyside. In a letter to Phil Evans, Pat Ciricillo wrote, "Bix did not take my piano out to Long Island. My piano was always in the 44th Street Hotel." 
Most likely, Ciricillo rented his piano to Bix in the summer of 1930 when he was gone for three months. It was in the summer of 1930 that Bix completed composing "Candlelight" and copyrighted it. Moreover, it is noteworthy that in July 1931, when Ciricillo went to Italy, Bix was no longer residing in the 44th Street Hotel: he had moved, with Alice's help, to Sunnyside. Furthermore, when Bix's brother Burnie went to Sunnyside in August 1931, he saw a piano in Bix's apartment and thought it was the Weber family grand piano. It is highly unlikely that Burnie would confuse a baby grand piano with Ciricillo's upright piano.

Joan Fabrizio, Alice's niece, told Albert Haim that when Bix died, Alice had the choice of having the piano or the cornet and she chose the piano. Loretta Weiss, Alice's grandniece, asked her about the piano and Alice answered, "It belonged to a dear friend who died very young." Thus, it is evident that the piano Bix had in his apartment in Sunnyside was the one he purchased when he moved to the apartment he had rented in Sunnyside. ${ }^{33}$ Bix's piano was in Alice Weiss's house in West Islip when she died in 1982:

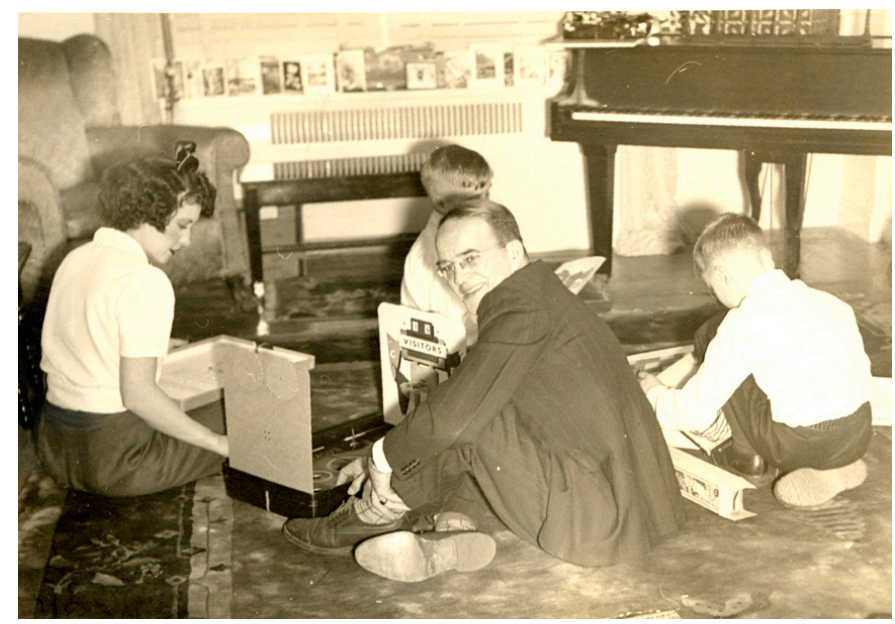

Figure 41. Alice and Max Weiss in the Living Room of the House in West Islip. Courtesy Patricia Weiss

Alice's sister, Vera, inherited the house in West Islip. When Vera died, Joan Fabrizio, executrix of the estate, with the help of Alice's grandniece Patricia Weiss (who lived on Long Island) had an estate sale in 1995. Patricia informed Albert Haim that the piano was purchased by Long Island resident Nick

\footnotetext{
${ }^{33}$ It is possible that Bix purchased the Wurlitzer baby grand in the Astoria Music Store, 3519 30th Avenue Astoria, N.Y. 11103. The store has been in this location since 1922. Its website informs us that early music greats such as Louis Armstrong, Tony Bennett, Bix Beiderbecke, etc. have come to the store either to record or to buy merchandise http://astoriamusicstore.com/About_The_Store.html (accessed February 28, 2012).
} 
Buongervino. Soon after, he gave the piano to his son Nick, Jr. who lived in Hauppauge at that time. On February 8, 1998, Patrice Buongervino, Nick, Jr.'s wife, exchanged the piano for a grand piano at the Franklin and Camille Piano Store in Westbury. The piano store used to provide, free of charge, pianos to Hofstra University in an alliance with Yamaha. At the end of each year, the Franklin and Camille Piano Store would bring additional pianos to the college and hold a piano sale on campus. On August 13, 1998, Shoshana and Gerald Tauber purchased the piano at the campus sale. In February 2011, the Taubers sold their home in Lawrence, New York, to Moshe and Elizabeth Mandel. At the time the house was sold, the piano was left in the house.

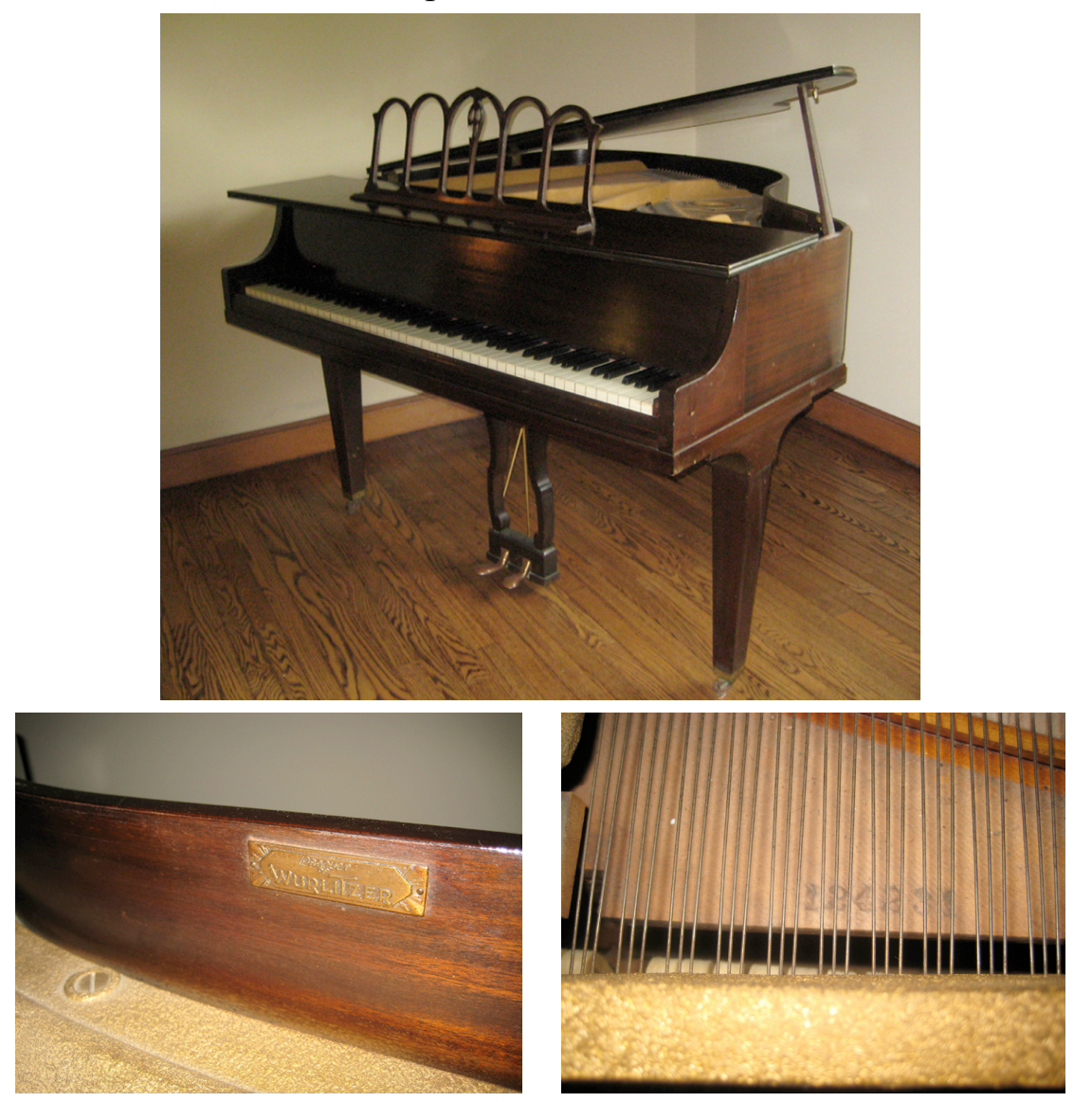

Figures 42A-C. Photos of Bix's Wurlitzer Piano. Taken by Albert Haim in May 2012 in the Home of Moshe and Elizabeth Mandel.

The following table presents serial numbers and dates for Wurlitzer pianos. The serial numbers given correspond to the first pianos manufactured in the years listed. 


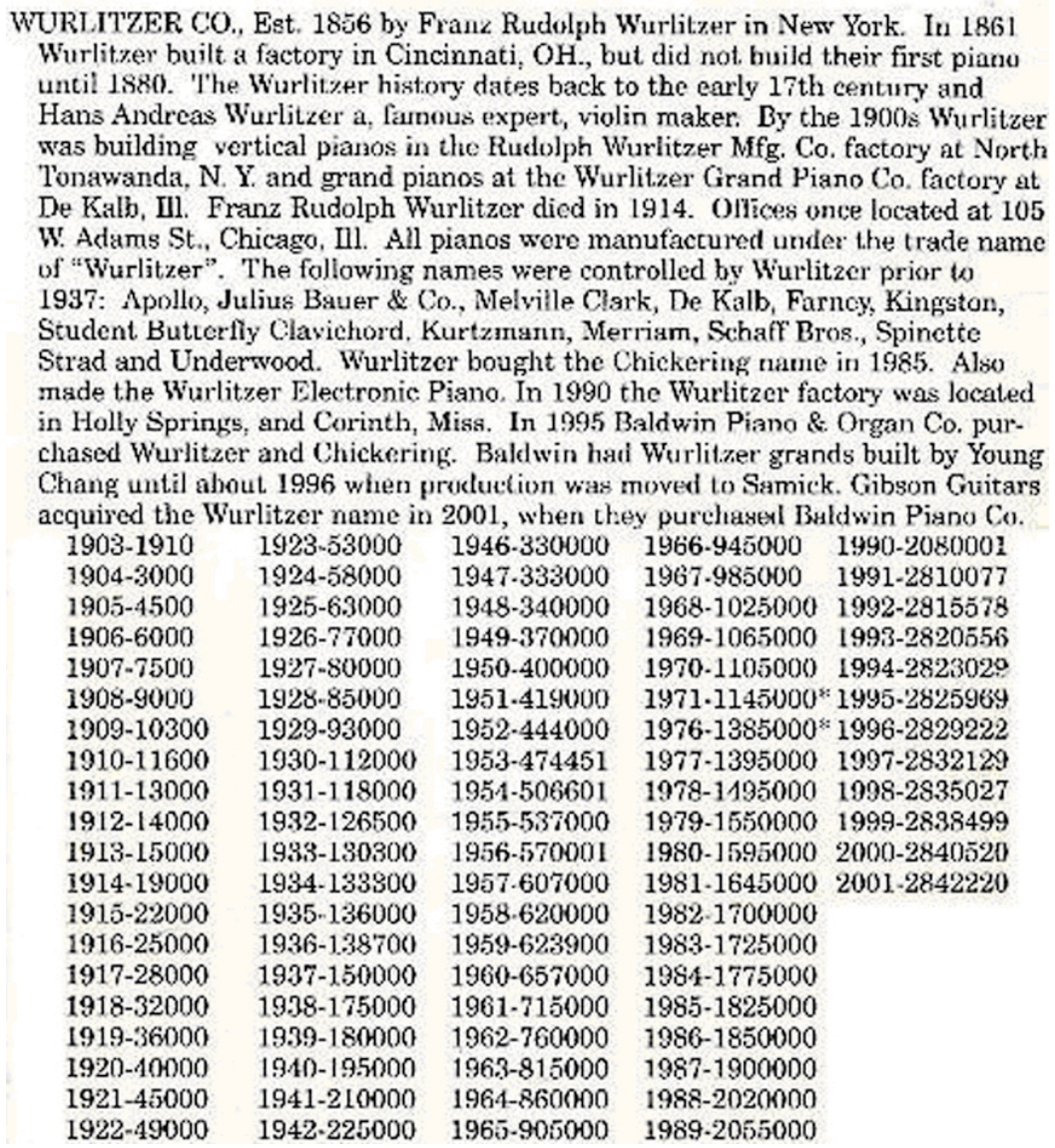

Figure 43. Serial Numbers and Dates of Wurlitzer Pianos. From Pierce Piano Atlas, 12th edition.

The serial number on the piano in question is 124231 , which indicates that it was manufactured in 1931. This is in agreement with the fact that Bix purchased this piano in $1931 .^{34}$

Albert Haim purchased Bix's piano from the Mandels on October 26, 2012. The piano is currently on permanent loan to the Bix Beiderbecke Museum and Archive in Davenport, Iowa.

\footnotetext{
${ }^{34}$ Some records of the Wurlitzer Company are available in the Smithsonian Institution. Unfortunately, the ledgers for Wurlitzer grand pianos are fragmentary, and no information about the Wurlitzer baby grand piano with Serial Number 124231 has been found. We made inquiries with archivists at Northern Illinois University, the Smithsonian Institution and the Mechanical Music Digest. The response was invariably the same: records that provide the location of the Wurlitzer retail store to where Wurlitzer grand pianos were shipped once manufactured was completed are not extant.
} 
APPENDIX

$$
\begin{aligned}
& \text { in sovalow-tuils and } 1 \text { Tuesday } \\
& \text { divected. } 3 \text { meros } \\
& \text { arond the \&uglana }
\end{aligned}
$$

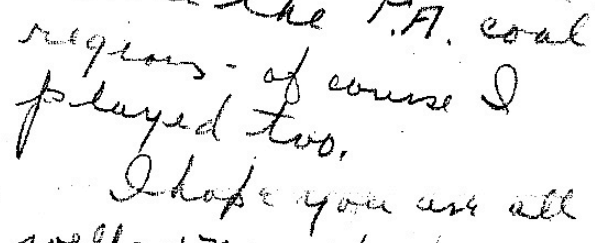

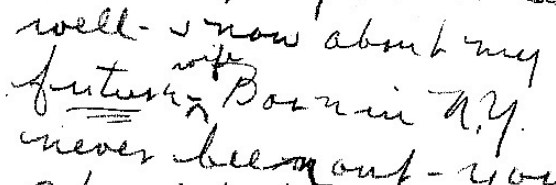

$$
\begin{aligned}
& \text { ohoritel bont-you }
\end{aligned}
$$

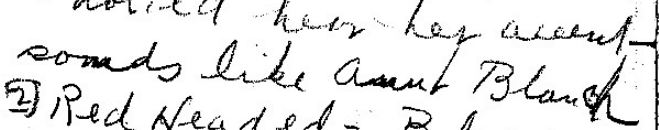

$$
\begin{aligned}
& \text { 2) Ped Neaded-Bhe sys }
\end{aligned}
$$

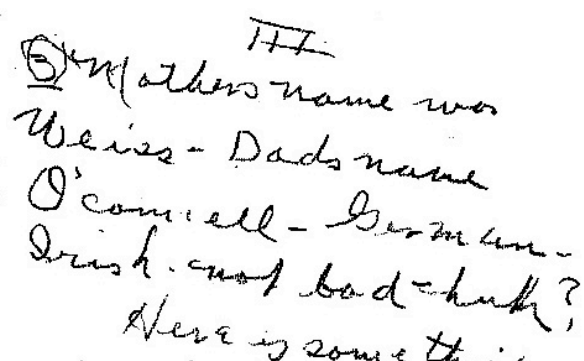
that bive beendreading to oay becains a of minathershe's a otannch catholus ahe has dragqed mue to

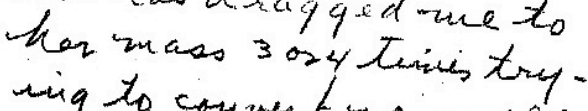
wing to con we twe, and lá taker her to the 5 of ave, pren chinch-atienyo

$$
\begin{aligned}
& \text { ahe libus it but her } \\
& 2 \text { brotheres } 3 \text { ainters } \\
& \text { would equeat - l plaqed } \\
& \text { golf with one of the } \\
& \text { brothen and he wow wer } \\
& \text { broud uninided about is } \\
& \text { wow if } Q \text { com awing to } \\
& \text { sisteno - Theirice are }
\end{aligned}
$$

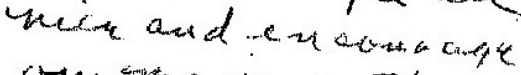

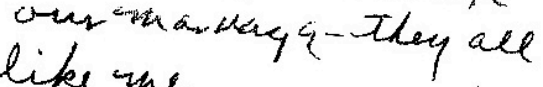

$$
\begin{aligned}
& \text { e litard Alicischas } \\
& \text { ruouldoit qet omarsia } \\
& \text { untel } e \text { had a carrbe }
\end{aligned}
$$


40

Journal of Jazz Studies

no pictures oo eldragqed her in to a Photometer wi the city and for a buck we gat this huge picture -alice de duct moat me to send it to you mantel a he gat $a$ ga ad one ma du. 7 his. will quire you an ide y of her.

thew another and facer died when she was quite

$\mathbb{Z}$

young - 7 hey apparently were very watch. Alice

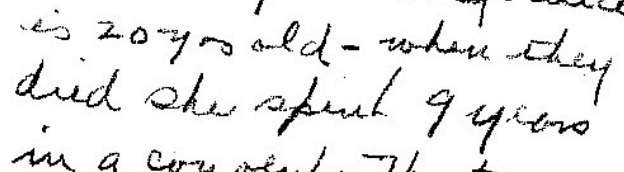
in a consents: The two brother 3 other ais ting all had a optic an the estate-lship aria $\therefore$ mo r th 10000 at leash with for bon tex ewe diulu't kina ra it.

TEAR THIS UP
V:

thous and -she vomited al me and o aid "yours got et" and showedure a bank b-aop-lahmiost swarmed a he's gat bonus bank sticks ate and plenty in the bant of a promise you that 2 fell in love with hes before liner that.

Sin sen ding a future oTher what do you her

VIII

Q have two offers founding and bim thanking buthover-therine bath ot lakes out eide of NIY. - so a can sone in for rand do the high orthbidur wins - lie give you my definitive a doles in a fer dayo-mite then -2460 3 2 nd at astor a Ps. Neater bes bore है। 


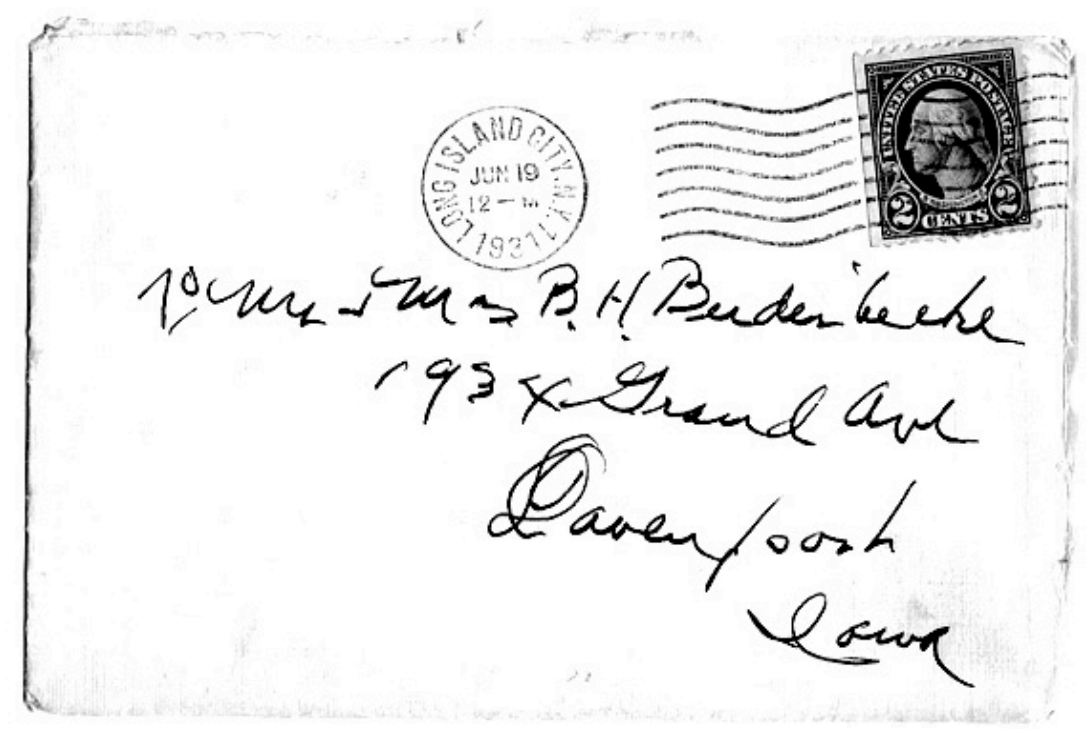

Figures 3A-E. Letter From Bix to His Parents. Pages 1-4 and Envelope. Courtesy of the Bix Museum and Archive, Davenport, lowa.

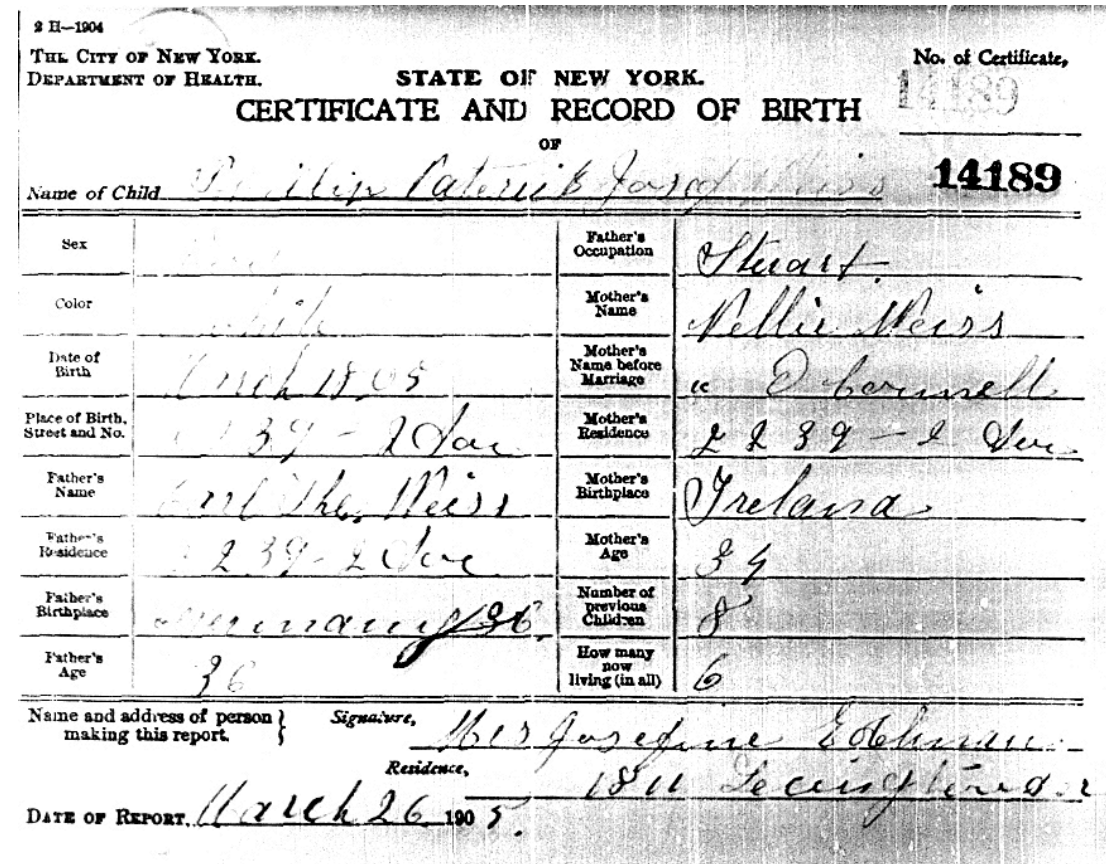

Figure 9. Birth Certificate of Philip Weiss 


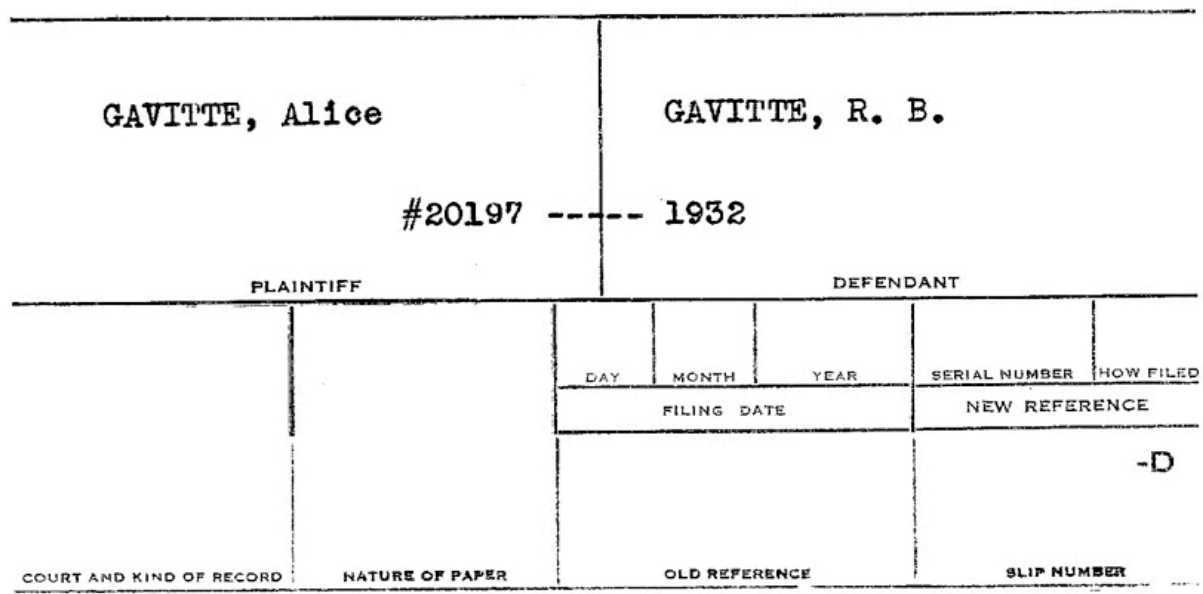

Figure 16. Filing for Divorce Alice Gavitte versus Rex Gavitte 


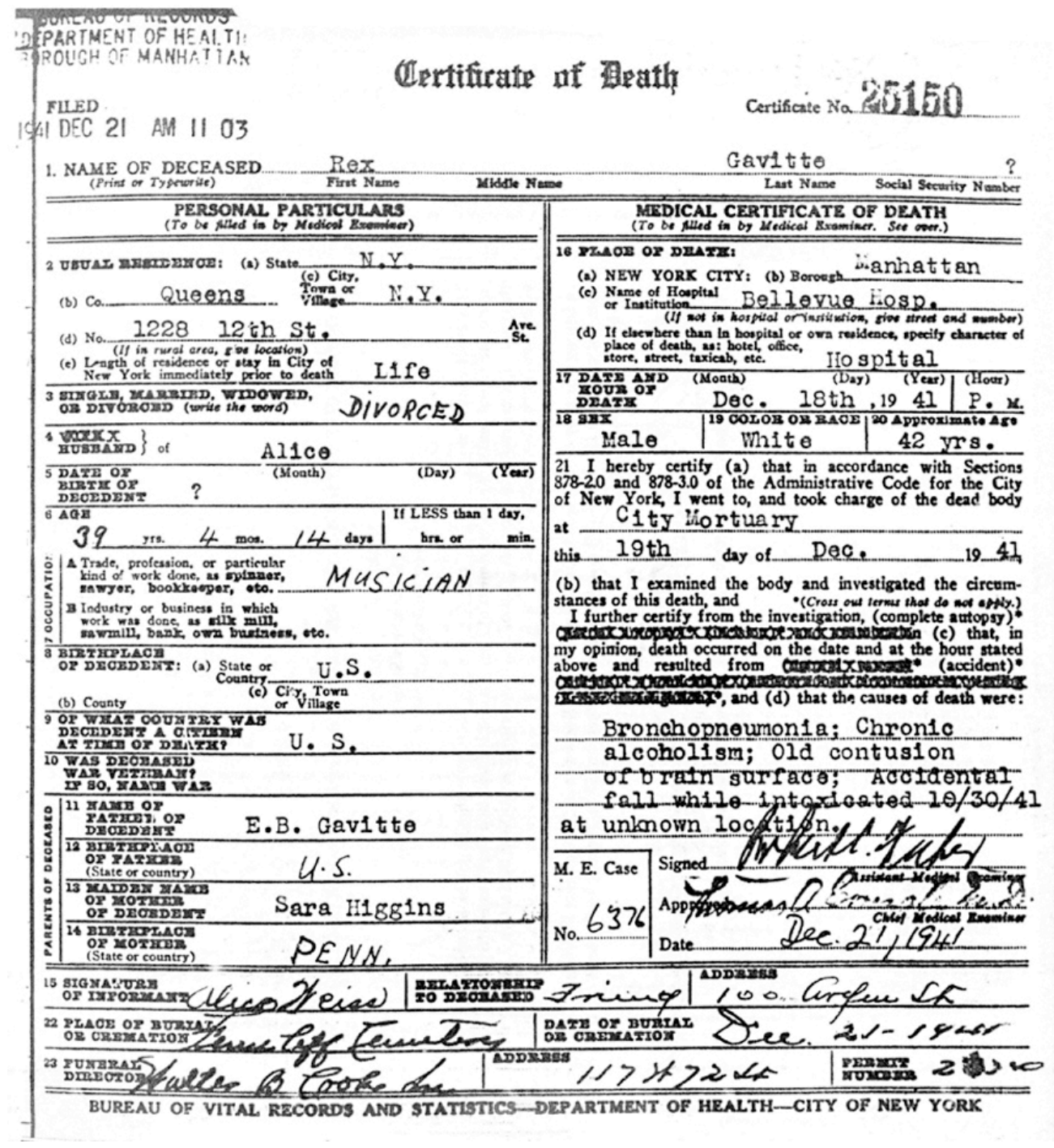

Figures 17A. Certificate of Death, page 1, Rex Gavitte. 


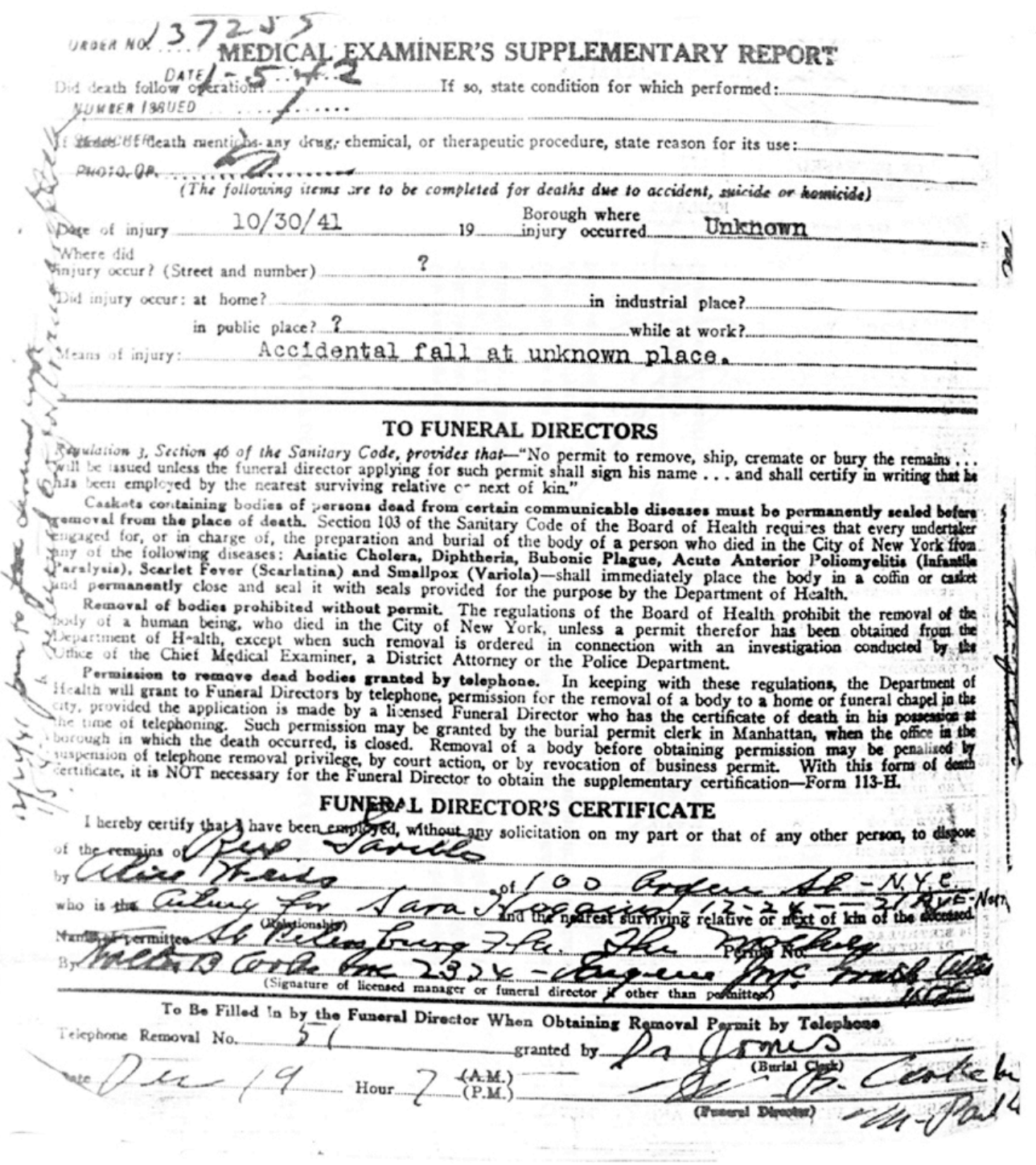

Figures 17B. Certificate of Death, page 2, Rex Gavitte. 


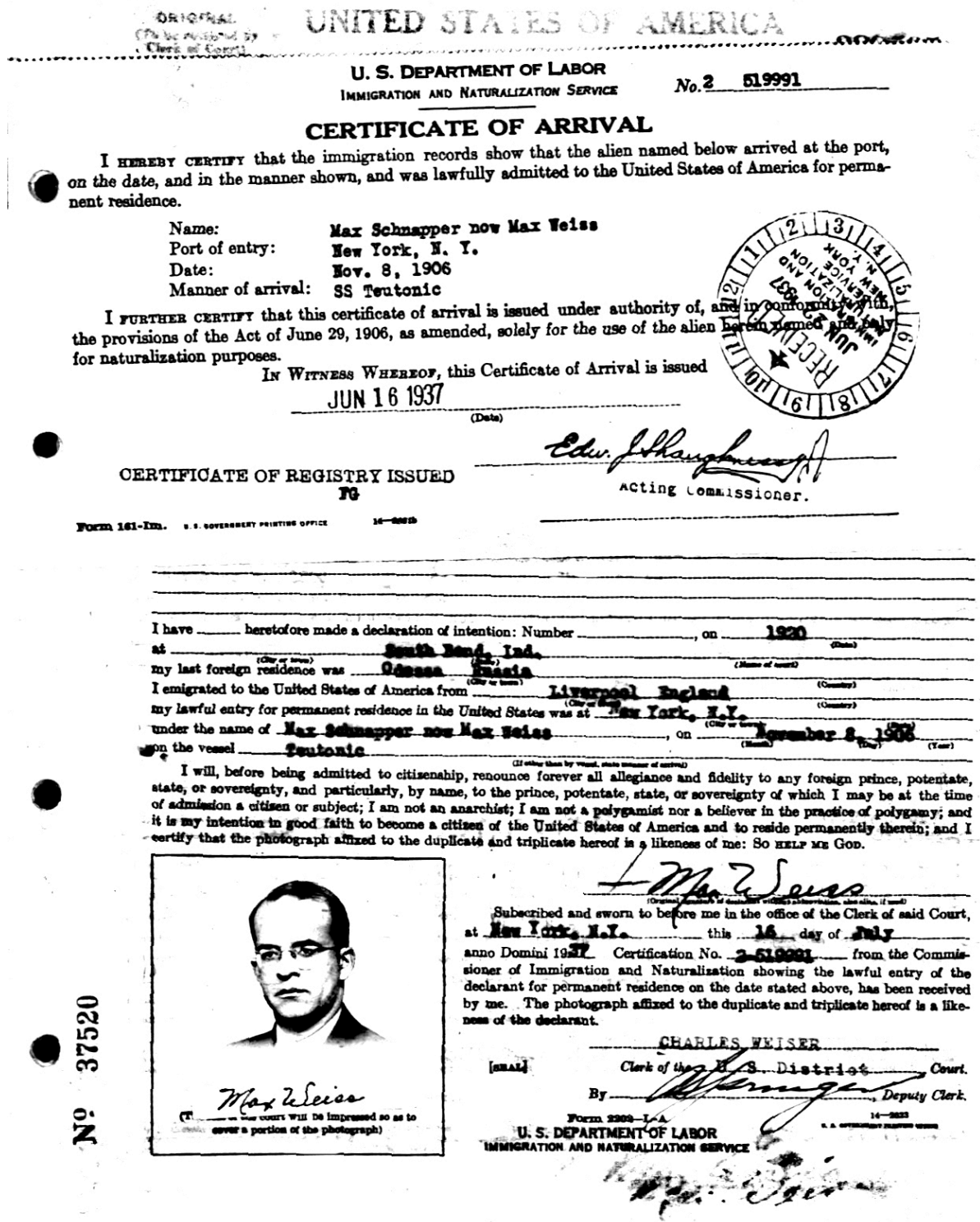

Figure 19 Certificate of Arrival to the US, Max Weiss 


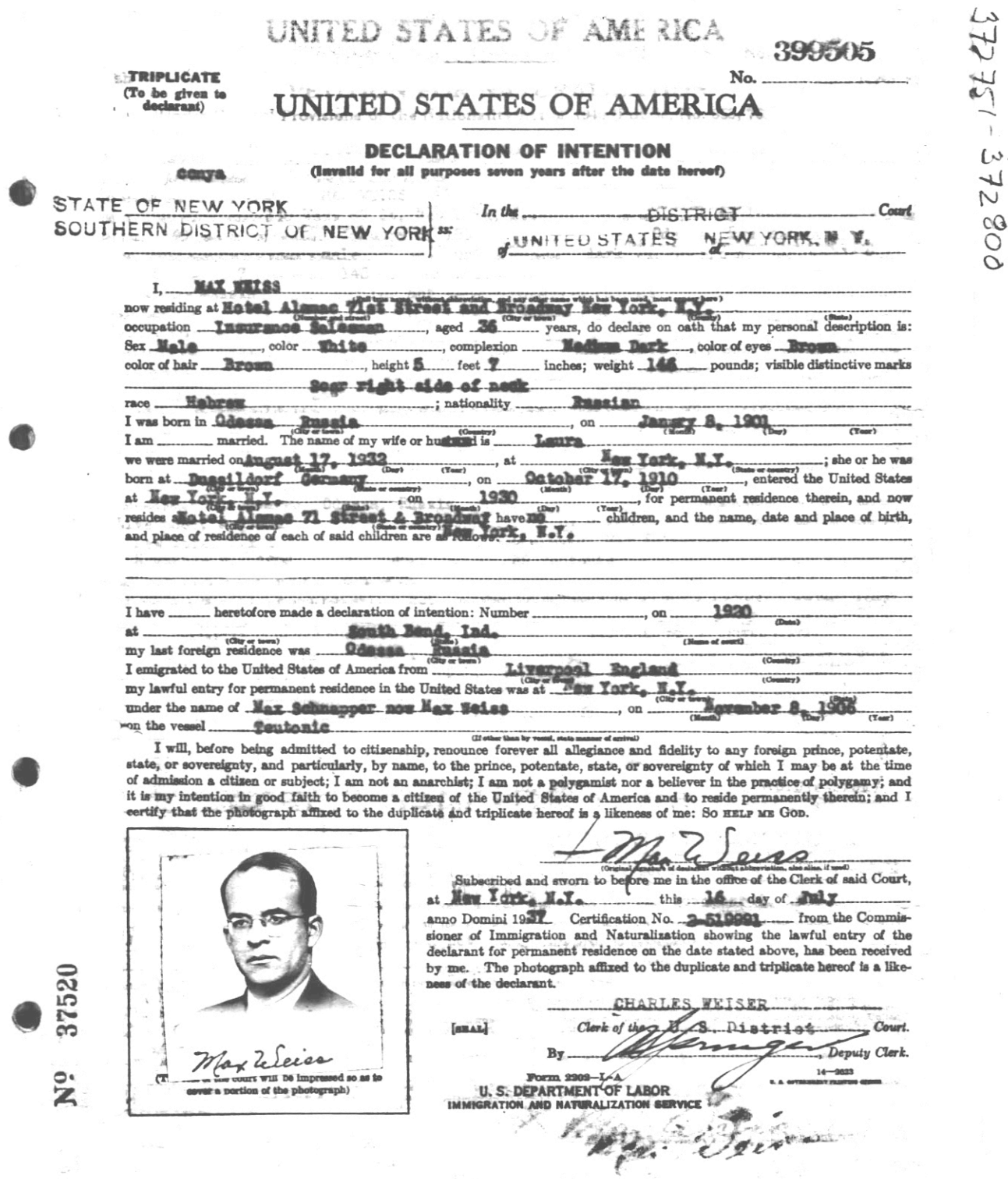

Figure 20 Declaration of Intention for Naturalization, Max Weiss 


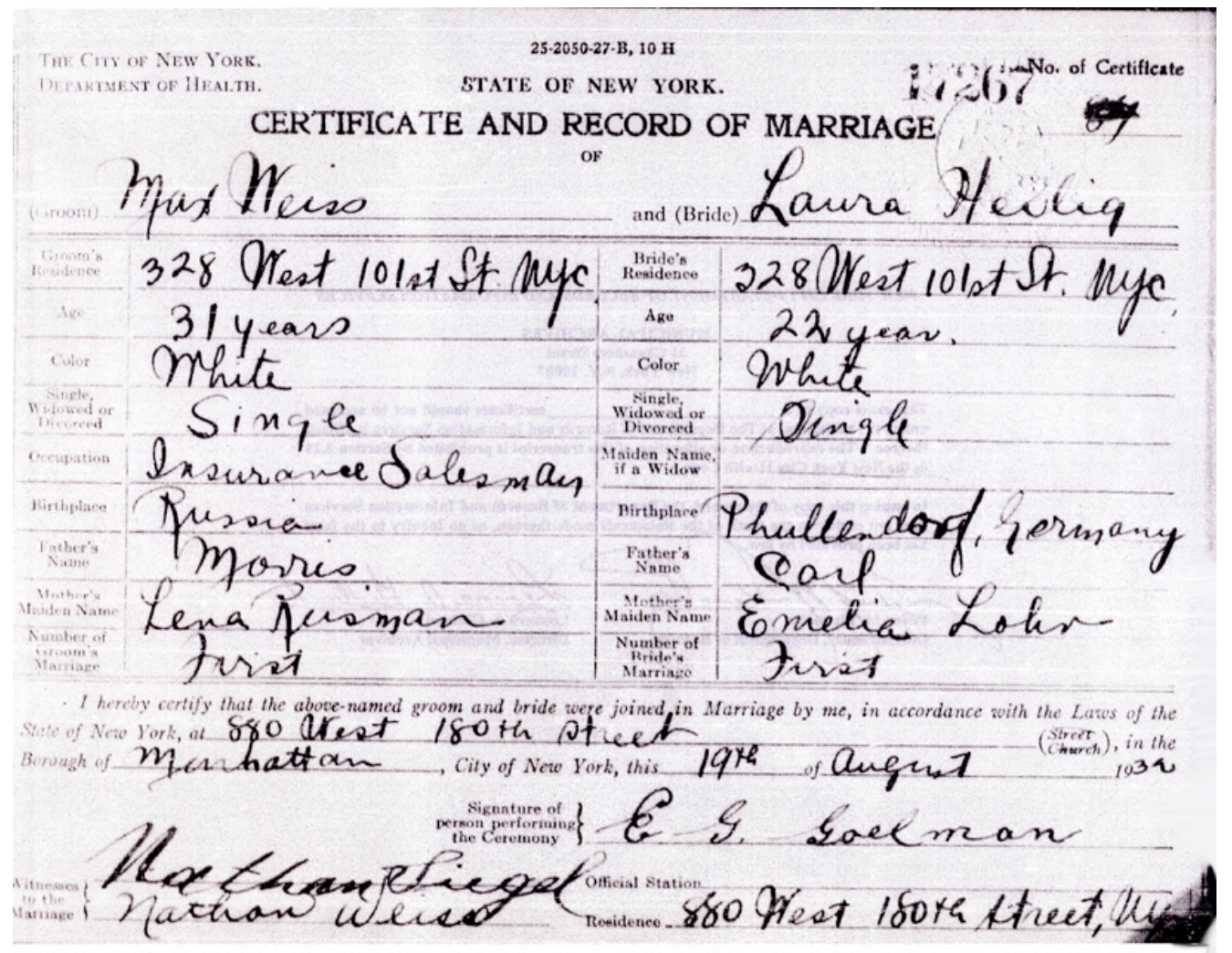

Figure 21. Certificate of marriage, Max Weiss and Laura Helig 


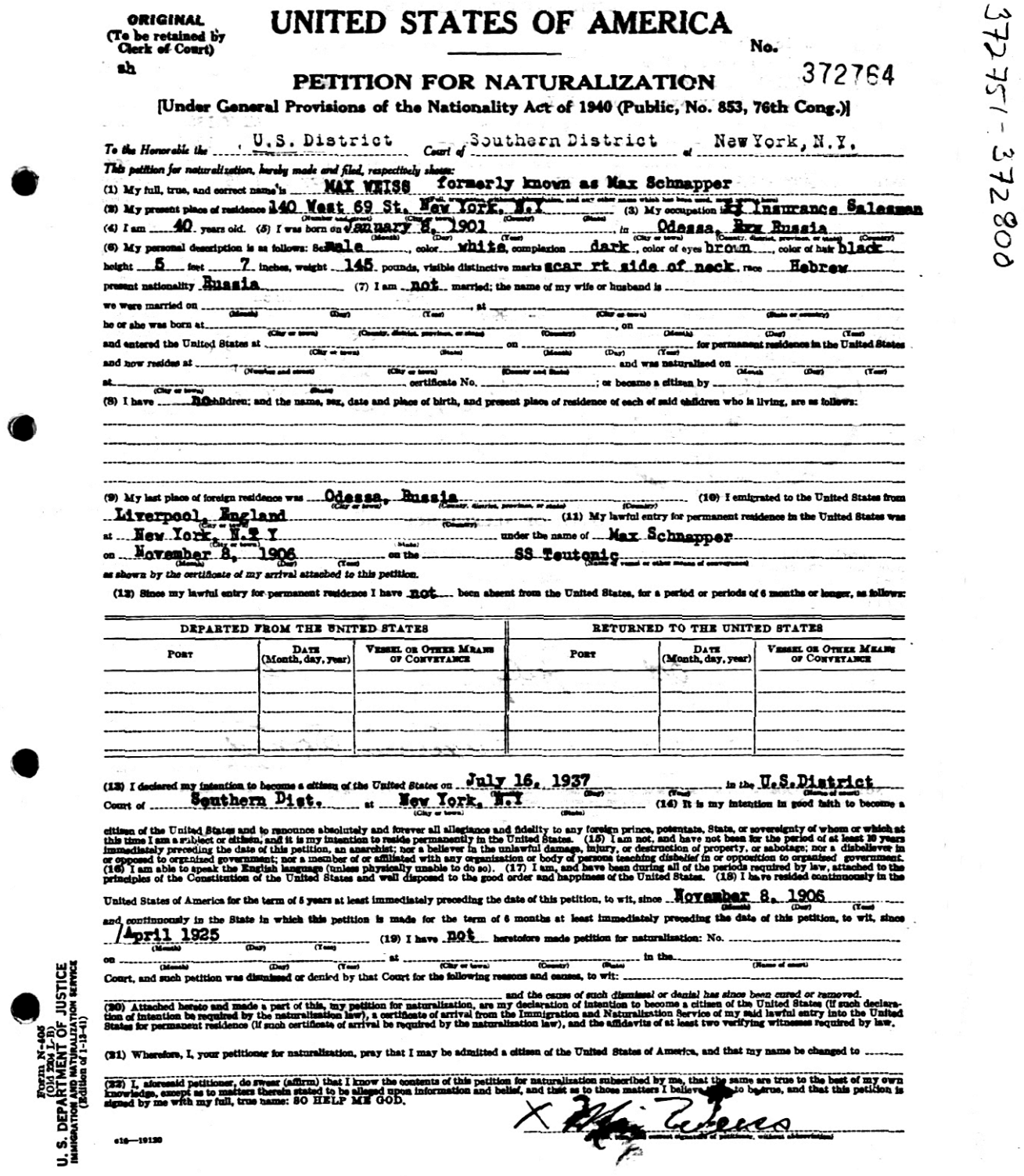

Figure 22 A. Petition for Naturalization, page 1Max Weiss. 


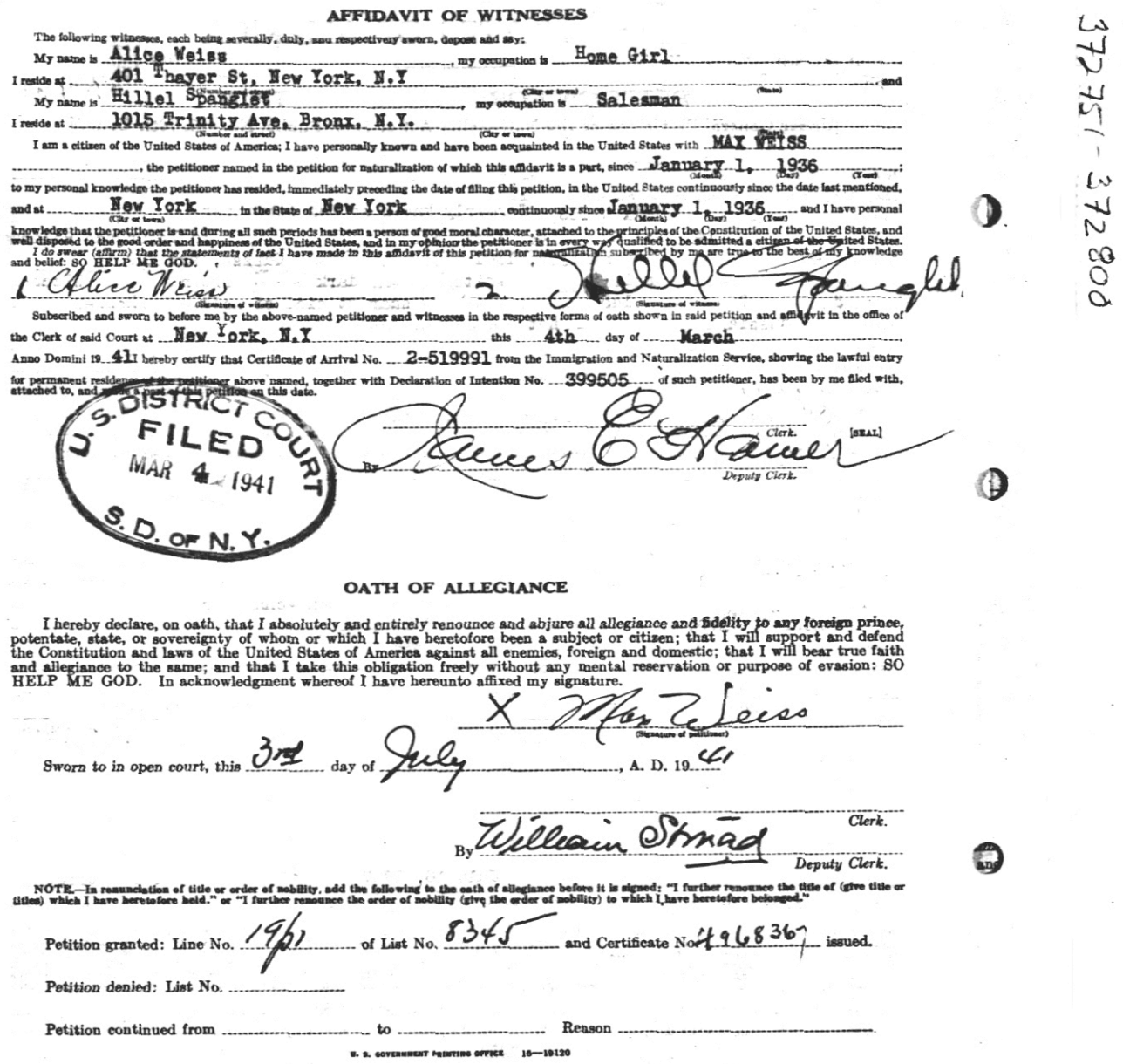

Figure 22 B. Petition for Naturalization, page 2. Max Weiss. 


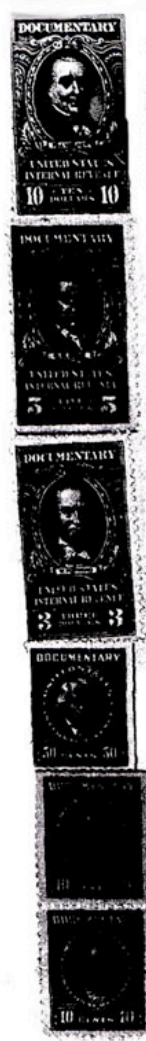

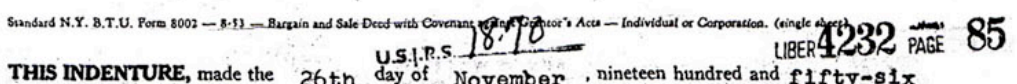
BETWEEN JOHN M. ARD and DORIS C. ARD, his wife, residing Route 2 . Box 99, Fort Plerce, State of Florida,

party of the first part, and MAX WEISS and ALICE CLAIRE WEISS, his wife, residing

at 145 Seaman Avenue, New York City, New York,

party of the second part,

WITNESSETH, that the party of the first part, in consideration of Ten Dollars and other valuable consideration paid by the party of the second part; does hereby grant and release
or successors and assigns of the party of the second part forever,

All that certain plot, piece or parcel of land, with the buildings and improvements thereon erected, situate,
lying and being at of New York, bounded and described as follows: BEGINNING at a point on the easterly side of West Islip Road at the southwesterly corrier of land of Michael J. Ryan, sald point beling 2340.75 feet more or less, southerly measured along sald easterly side of West IsIfp Road from the southerly side of South Country Road; hunning thence South $83^{\circ} 25^{\prime}$ 1 $0^{n}$ Fast along land of Ryem 321 foot more los the or less to the shore Ilne of a polnt being 100 feet southerly messured at right angles to the southerlv line of land of Ryan; running thence North $83^{\circ} 25^{\circ} 10^{\prime \prime}$ west parallel along land last mentioned and 100 feet distant southerly therefrom 277 feet more or less to the easterly side of sald West IsIIp Road; running thence North $20^{\circ} 10^{\prime} 40^{\prime \prime}$ West along sald side of West Islip Road, 93.93 feet; running thence st1ll along sald side of West Islip Road along a circular curve having a radius of 287.83 feot and turning to the right a distance of 17.80 feet to point or place of beginning.

TOGETHER with all the right,title and interest of party of the first part in and to the land under vater in the canal adjoining the premises above described, 1t being understood and agreed, however, that party of the second part, their holrs or assigns shall not at any time obstruct or injure in any manner, whatsoever, free passage over and accross the waters of sald canal adjolning sald premises. of record.

SUBJECT TO covenants, restrictions, easements and reservations SUB JECT to a mortgage, now a lien on sald premises, held by Suffolk County Federal Savings and Loan Assoclation, in the sum of $\$ 12,000.00$, presently reduced to $\$ 10,340.95$.

TOGETHER with all right, title and interest, if any, of the party of the first part of, in and to any streets and roads abutting the above-described premises to the center lines thereof; TOGETHER with the appurtenenoe: and all the estate and rights of the party of the first part in and to said premises; TO HAVE AND TO the party of the second part forever. AND the party of the first part covenants that the party of the first part has not done or suffered anything AND the party of the firs part, in compliance with Section 13 of the Lien Io covestints that the party of the first part will receive the consideration for this conveyance and will hold the right to receive such consideration 2 a trust fund to be applied first for the purpose of paying the cost of the improvement and will apply the same first to the payment of the cost of the improvement before using any part of the total of the same for any other purpose.

The word "party". shall be construed as if it read "parties" whenever the sense of this indenture so requires. IN WITNESS WHEREOF, the party of the first part has duly executed this deed the day and year first above written.

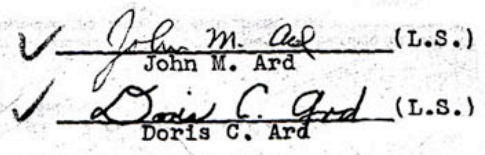

Figure 27. Sale Deed for House at 185 West Islip Road, West Islip, 


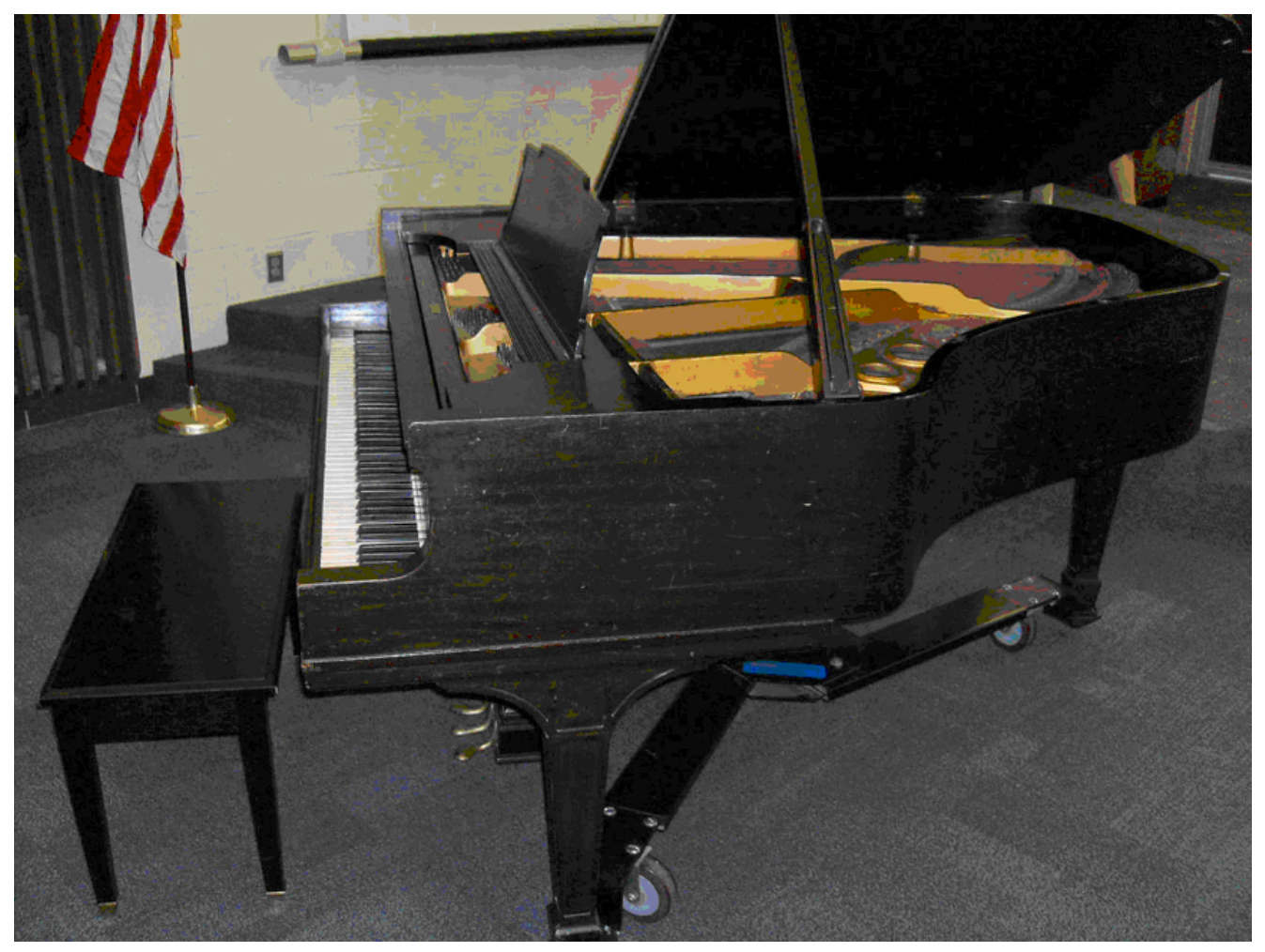

Figure 38. Beiderbecke Weber Family Piano. Putnam Museum, Davenport, lowa. Photograph courtesy of Jim Petersen.

\section{ACKNOWLEDGMENTS}

This article could not have been written without the invaluable cooperation and generosity of several members of the Weiss family: nieces Joan Phyllis Fabrizio (neé Weiss) and Alice Clare Kimble (neé Weiss), grandnieces Patricia Weiss and Loretta Weiss, and grandnephews Raymond Weiss, Jr., and Douglas Weiss. They provided innumerable and precious family photos, and they patiently answered our unending questions. Their invaluable help is deeply appreciated. The piano that Bix Beiderbecke purchased in 1931 could not have been located without the help of Patricia Weiss and Camille Scheiderman: one of us (AH) is eternally grateful to them. We are grateful to Christine S. Windheuser, Smithsonian Institution, NMAH Archives Center, Volunteer Reference Assistant; Robert T. Furst, Archivist, Bluebook of Pianos; and Jody Kravitz, Editor Mechanical Musical Digest for their help with information about Wurlitzer pianos. Our sincere thanks go to Muriel Voss and Gerri Bowers for the scans of Bix's letters to his parents. Thanks to Robert 
Ciricillo for copies of letters from his father Pat to Phil Evans. Thanks also to the Robert F. Wagner Labor Archives at NYU's Tamiment Library, Ancestry.com, Philadelphia's Court of Common Pleas, the New York County Clerk's Office, New York City Municipal Archives, and the Bergen County (NJ) Clerk's Office. Thanks also to Leon County Public Library, Tallahassee, FL, Suffolk Historic Newspapers online, and the Babylon (NY) Public Library for copies of obituaries.

\section{ABOUT THE CONTRIBUTORS}

ALBERT HAIM is Professor Emeritus of Chemistry, Stony Brook University and the founder and Webmaster of bixbeiderbecke.com, a website completely dedicated to Bix Beiderbecke. He is the author of numerous articles in various jazz journals.

CHRISTOPHER R. BARRY has an interest in genealogy and in researching figures in early jazz history, especially those whose lives have not been chronicled previously. He has worked for ABC News Radio and is currently an assignment editor.

The Journal of Jazz Studies (JJS) is published by the Institute of Jazz Studies at the Newark campus of Rutgers, The State University of New Jersey. JJS is hosted online by the Rutgers University Libraries at http://jjs.libraries.rutgers.edu 